\title{
Sistem Informasi Kursus PHP dan MySQL
}

Iwan Purnama,S.Kom.,M.Kom

M.Kom - Ronal Watrianthos, S.Kom.,M.Kom

Uwais Inspirasi Indonesia 


\section{Perpustakaan Nasional RI}

Iwan Purnama,S.Kom.,M.Kom - Ronal Watrianthos, S.Kom.,M.Kom-Uwais Inspirasi Indonesia-Juli 2018-vii + 86

Judul: Sistem Informasi Kursus PHP dan MySQL

ISBN: 978-602-5891-27-4

\section{Penulis:}

Iwan Purnama,S.Kom.,M.Kom

M.Kom - Ronal Watrianthos, S.Kom.,M.Kom

Editor:

Fungky

Design Cover:

Sudi Suryadi,S.Kom.,M.Kom

Cetakan Pertama, Agustus 2018

Diterbitkan Oleh:

Uwais Inspirasi Indonesia

Ds. Sidoarjo, Kec. Pulung, Kab. Ponorogo

Email: Penerbituwais@gmail.com

Telp: 0352-571 892

WA: 0895-2366-1093/0823-3033-5859 
Sanksi Pelanggaran Pasal 113 Undang-Undang Nomor 28 tahun 2014 tentang Hak Cipta, sebagaimana yang telah diatur dan diubah dari Undang-Undang nomor 19 Tahun 2002, bahwa:

Kutipan Pasal 113

(1) Setiap orang yang dengan tanpa hak melakukan pelanggaran hak ekonomi sebagaimana dimaksud dalam pasal 9 ayat (1) huruf i untuk penggunaan secara komersial dipidana dengan pidana penjara paling lama 1 (satu) tahun dan/atau pidana denda paling banyak Rp100.000.000,00 (seratus juta rupiah).

(2) Setiap orang yang dengan tanpa hak dan/atau tanpa izin pencipta atau pemegang hak cipta melakukan pelanggaran hak ekonomi pencipta sebagaimana dimaksud dalam pasal 9 ayat (1) huruf $\mathrm{c}$, huruf $\mathrm{d}$, huruf $\mathrm{f}$, dan/atau huruf h, untuk penggunaan secara komersial dipidana dengan pidana penjara paling lama 3 (tiga) tahun dan/atau pidana denda paling banyak Rp500.000.000,00 (lima ratus juta rupiah).

(3) Setiap orang yang dengan tanpa hak dan/atau tanpa izin pencipta atau pemegang hak melakukan pelanggaran hak ekonomi pencipta sebagaimana dimaksud dalam pasal 9 ayat (1) huruf a, huruf $\mathrm{b}$, huruf e, dan/atau huruf $\mathrm{g}$, untuk penggunaan secra komesial dipidana dengan pidana penjara paling lama 4 (empat) tahun dan/atau pidana denda paling banyak Rp1.000.000.000.00 (satu miliar rupiah).

(4) Setiap orang yang memenuhi unsur sebagaimana dimaksud pada ayat (3) yang dilakukan dalam bentuk pembajakan, dipidana dengan pidana penjara paling lama 10 (sepuluh) tahun dan/atau pidana denda paling banyak Rp4.000.000.000.00 (empat miliar rupiah). 


\section{KATA PENGANTAR}

Bahasa Pemrograman Web (PHP, MySQL) sangat banyak digunakan perusahaan-perusahaan untuk membuat web, aplikasiaplikasi kreatif dan digunakan secara online maupun Offline seperti aplikasi dekstop.

Buku ini disusun berdasarkan pengalaman penulis yang telah cukup banyak berpetualang dalam dunia IT dan dikemas sesederhana mungkin, sehingga diharapkan pembaca dapat memperoleh manfaat dari buku ini.

Tak lupa penulis mengucapkan terima kasih kepada Orang Tua, penulis dokumentasi dan tutorial internet dan berbagai pihak yang telah membantu dalam penerbitan buku ini.

Penulis menyadari bahwa buku ini masih jauh dari kata sempurna, oleh karena itu kritik dan saran dari pembaca sangat penulis harapkan untuk melakukan penyempurnaan di masa yang akan datang.

Rantauprapat, Juli 2018

Tim Penulis 


\section{DAFTAR ISI}

Kata Pengantar.................................................................. iv

Daftar Isi .............................................................................

BAB 1 HTML ............................................................ 1

1.1. Apa Itu HTML ................................................ 1

1.2. Sejarah HTML ................................................ 2

1.3. Fungsi HTML..................................................... 2

1.4. Contoh Penggunaan HTML ..................................... 4

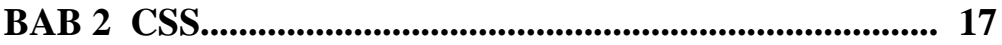

2.1. Apa Itu CSS ?.................................................... 17

2.2. Fungsi CSS ...................................................... 17

2.3. Contoh Penggunaan CSS ................................... 22

ВАВ 3 ХАМРP ….............................................................. 26

3.1. Apa Itu XAMPP ? ............................................ 26

3.2. Install Xampp .................................................. 26

3.3. Jalankan Xampp .............................................. 31

3.4. Membuat Database ............................................. 32

3.5. Membuat Tabel Phpmyadmin ................................ 32

3.6. Mengedit Tabel Phpmyadmin ............................... 35

3.7. Menghapus Tabel Phpmyadmin.............................. 37

BAB 4 MEMBUAT SISTEM INFORMASI KURSUS ...... 40

4.1. Membuat Database Kursus ..................................... 40

4.2. Membuat Skrip PHP ........................................... 41

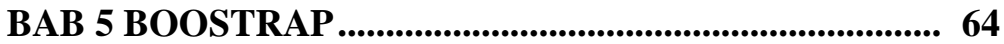

5.1. Pengertian Boostrap ................................................. 64

5.2. Install Boostrap ..................................................... 65

5.3. Desain Web PHP Dengan Tema Boostrap.............. 66

Daftar Pustaka ................................................................... 67 



\section{BAB 1}

\section{HTML}

\subsection{Apa itu HTML?}

HTML atau yang merupakan singkatan dari Hypertext Mark Up Language adalah bahasa standar pemrograman untuk membuat suatu website yang bisa diakses dengan internet. Dengan kata lain halaman website yang kita lihat dan kita baca disusun dengan menggunakan bahasa ini dan kemudian diterjemahkan oleh komputer agar dapat dipahami oleh penggunanya. Html merupakan standar pembuatan website secara luas agar laman website dapat ditampilkan pada layar komputer.

HTML disusun dengan kode dan simbol tertentu yang dimasukkan ke dalam sebuah file atau dokumen. Jadi setiap Anda membuka website apapun dengan menggunakan browser maka web tersebut dibuat dengan menggunakan html.

Dari singkatan hypertext markup language itu sendiri kita bisa mengetahui makna dari html. Hypertext adalah suatu metode yang digunakan untuk berpindah laman web ke laman yang lain dengan mengklik suatu tulisan atau simbol pada laman website.

Istilah markup pada html sendiri diartikan sebagai suatu hal yang dilakukan tag html terhadap teks yang berada di dalamnya, misal jika mengetik suatu teks dengan tanda tag $\langle$ b $\rangle$ maka teks tersebut akan 
muncul sebagai teks dengan huruf tebal atau bold pada suatu laman website.

Simbol atau tag html tersebut ditulis pada laman html yang sudah disediakan pada dashboard website pada umumnya. Sementara language dalam html adalah bahasa pemrograman atau script yang disusun dari tag-tag tertentu yang nantinya akan diterjemahkan kedalam teks atau visual yang dapat dilihat pada website.

\subsection{Sejarah HTML}

Markup language atau yang kini dikenal sebagai html awalnya diciptakan oleh suatu perusahaan penjual perangkat keras dan lunak yakni IBM atau International Bussiness Machines. Sekitar tahun 1980, IBM menciptakan sebuah bahasa yang menggabungkan tag atau simbol dengan teks dalam sebuah dokumen.

Bahasa yang diciptakan oleh IBM tersebut dikenal dengan sebutan markup language atau Generalized markup language (GML). Selanjutnya ditahun 1986, ISO atau International Standart Organization mengeluarkan pernyataan bahwa GML yang kemudian diubah istilahnya menjadi SGML (Standart Generalized Markup Language) ditetapkan sebagai standar dalam membuat berbagai dokumen yang bisa membantu dalam bisnis maupun pekerjaan lainnya.

\subsection{Fungsi HTML}

Html yang dikenal sebagai bahasa pemrograman dalam ilmu komputer memiliki beberapa fungsi, diantaranya adalah sebagai berikut: 
1. Fungsi utama html yang diketahui adalah untuk membuat suatu halaman website yang bisa dibaca dan dipahami oleh pengguna dengan lebih mudah. Seluruh laman website yang ada dalam internet dibuat dengan html dan tidak ada pengecualian.

2. Menandai teks pada suatu laman, html ditulis pada suatu halaman dokumen dengan tag atau simbol tertentu dimana simbol dan tag tersebut akan menandai teks menjadi tebal, miring, bergaris tebal dan lain sebagainya. Misal jika kita membuat suatu teks menjadi teks miring atau italic, dalam laman html dituliskan kode $\langle\mathrm{i}\rangle,\langle\mathrm{b}\rangle$ untuk teks tebal dan $\langle\mathrm{u}\rangle$ untuk teks bergaris bawah.

3. Sebagai dasar website, website yang dibuat tentunya memiliki beberapa fitur yang dibuat dengan menggunakan java script (untuk mengatur perilaku web), implemetasi bahasa pemrograman server PHP, dan mendesain web menggunakan CSS. Semua bahasa tersebut dapat diaplikasikan jika web memiliki bahasa html sebagai dasarnya.

4. Menampilkan tabel, gambar, video, dan lainnya. Biasanya dalam website atau blog kita tidak bisa langsung meletakkan tabel, gambar maupun video oleh sebab itu komponen tersebut diletakkan pada web dengan menggunakan bahasa html.

5. Menandai elemen dan membuat online form, html juga berfungsi untuk menandai bagian-bagian dalam website diantaranya header, main, footer, navigation dan lain sebagainya. Selain itu html juga biasanya digunakan sebagai bahasa dalam membuat suatu online form atau formulir digital. 


\subsection{Contoh Penggunaan HTML}

1. Membuat Paragrap dengan HTML

\section{paragrap.html}

$<$ ! DOCTYPE html>

$<$ html $>$

$<\mathrm{body}>$

<h1>Judul Paragrap Menggunakan Heading $1</$ h1 $>$

$<$ h2> Judul Paragrap Menggunakan Heading $2</$ h2 $>$

<h3>Judul Paragrap Menggunakan Heading $3</$ h3 $>$

<h3>Judul Paragrap Menggunakan Heading 4</h3>

$<$ p $>$ Contoh Paragrap $</$ br $></ p>$

$<$ p selamat Datang di Sistem Informasi Kursus. Sistem Informasi Kursus ini berbasis Web PHP dan MySQL $</ p>$

$</$ body $>$

$</$ html $>$

\section{Akhir}


localhost/dasarhtml/para $\times$

$\leftarrow \rightarrow$ C (i) localhost/dasarhtml/paragrap.html 岤 :

\section{Judul Paragrap Menggunakan Heading 1}

Judul Paragrap Menggunakan Heading 2

Judul Paragrap Menggunakan Heading 3

Judul Paragrap Menggunakan Heading 4

Contoh Paragrap

Selamat Datang di Sistem Informasi Kursus. Sistem Informasi Kursus ini berbasis Web PHP dan MySQL

Gambar 1.1 Membuat Paragrap dengan Html 


\section{Membuat Link dengan HTML}

\section{link.html}

$<$ h2 $>$ Menu $</$ h2 $>$

$<$ a href="\#" $>$ Home $</ a>$

$<a$ href="paragrap.html" $>$ Paragrap $</ a>$

$<$ a href="link.html" $>$ Link $</ a>$

$<$ a href="image.html" $>$ Gambar $</ a>$

\section{Akhir}




\section{Membuat List/Daftar dengan HTML}

\section{link.html}

$<$ ul $>$

$<$ li $>$ Kursus Aplikasi Perkantoran $</ l i>$

$<$ li>Kursus Desain Grafis $</ l i>$

$<$ li>Kursus Pemrograman (PHP, VB. Net, Android) $</ l i>$

$<$ li>Kursus Teknisi Komputer</li>

$<$ li $>$ Kursus Desain Grafis $</ l i>$

$</ u l>$

\section{Akhir}




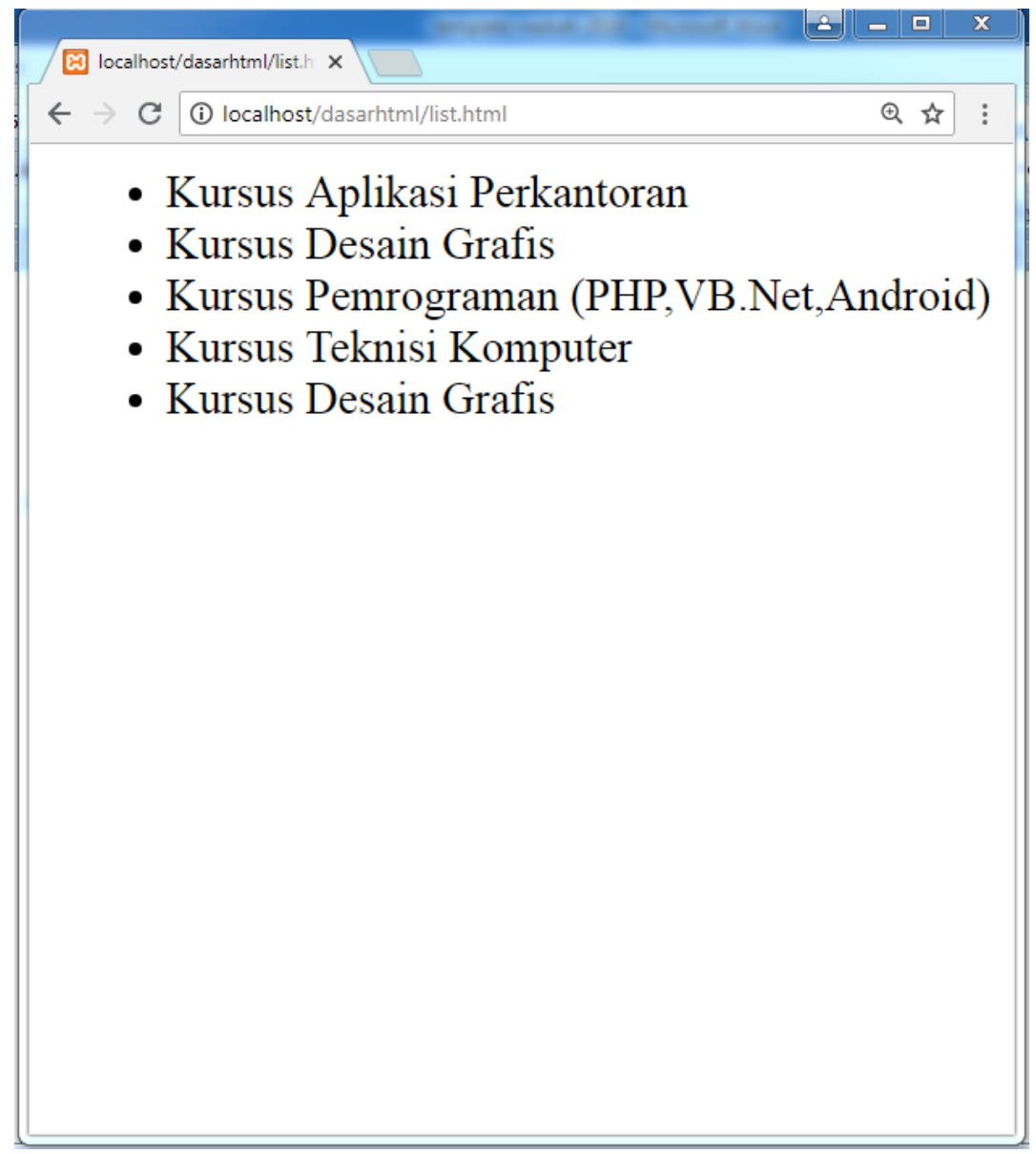

Gambar 1.3 Membuat Link dengan Html 
4. Membuat Tabel dengan HTML

\section{tabel.html}

<!DOCTYPE html>

$<$ html $>$

$<$ head $>$

<style $>$

table \{

font-family: arial, sans-serif;

border-collapse: collapse;

width: $100 \%$;

\}

td, th \{

border: 1px solid \#dddddd;

text-align: left;

padding: 8px;

\}

tr:nth-child(even) \{

background-color: \#dddddd;

\}

$</$ style $>$

Sistem Infarmasi Kursus PHP dan MySQL 


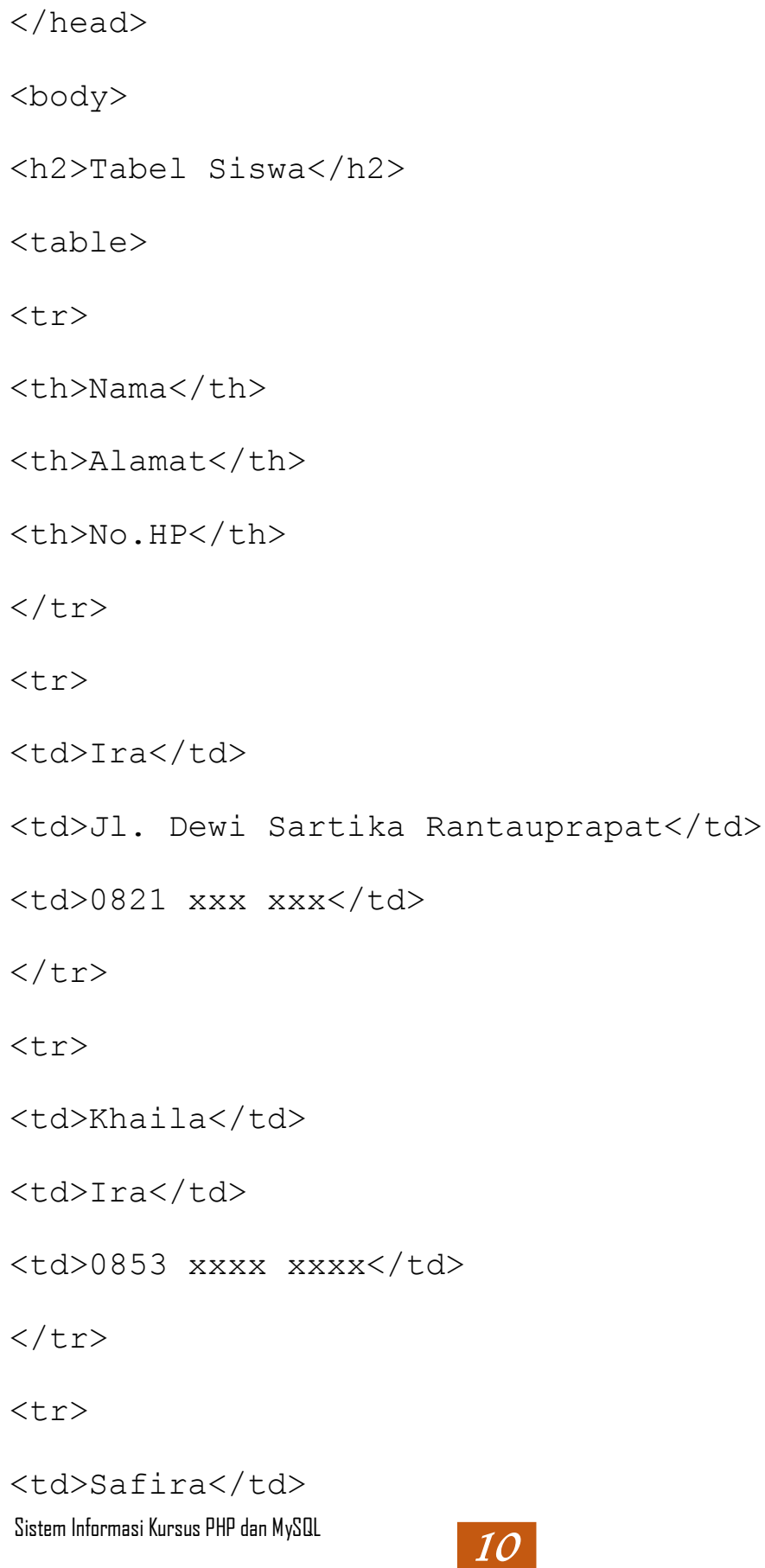




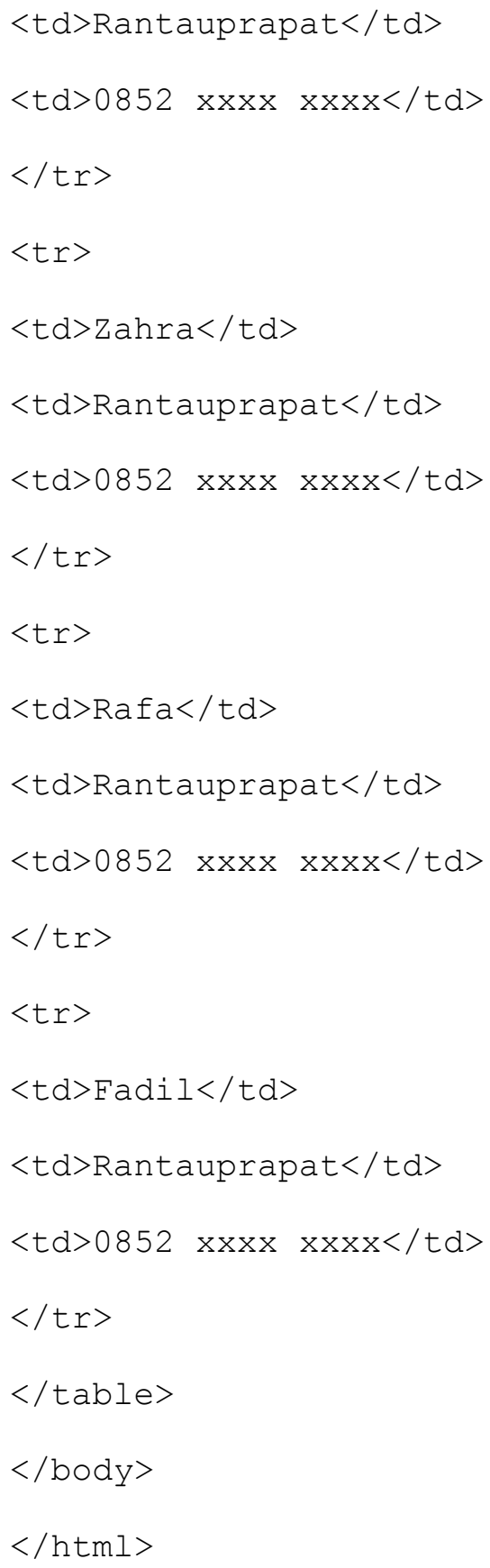




\section{Akhir}

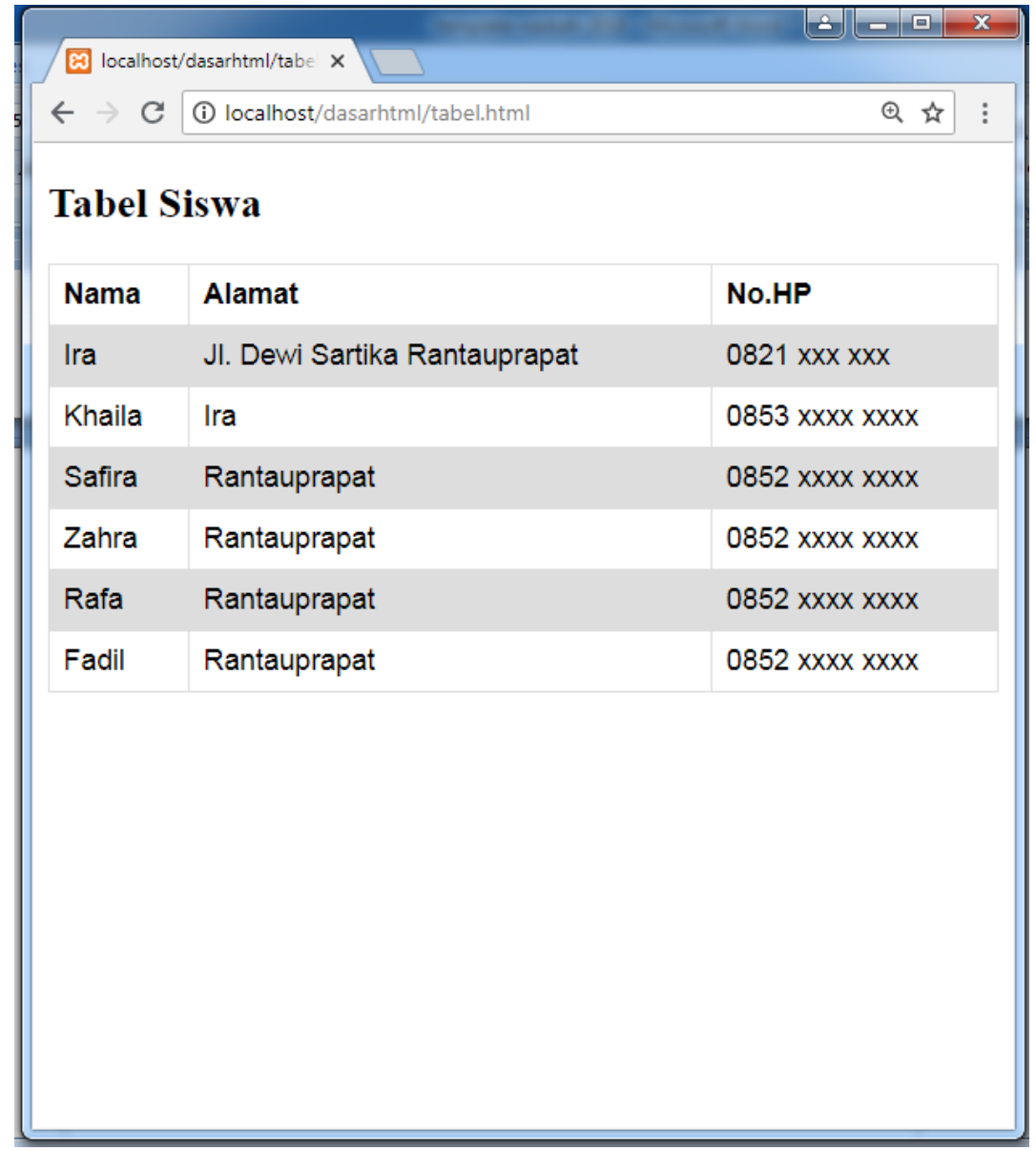

Gambar 1.4 Membuat Tabel dengan Html 
5. Menampilkan gambar/image dengan Html

\section{image.html}

<img src="gambar-php.png" alt="php" width="100" height="100">

<img src="gambar-php.png" alt="php" width="150" height="150">

<img src="gambar-php.png" alt="php" width="200" height $=" 200 ">$

<img src="gambar-php.png" alt="php" width="250" height="250">

<img src="gambar-php.png" alt="php" width="300" height="300">

<img src="gambar-php.png" alt="php" width="350" height="350">

\section{Akhir}




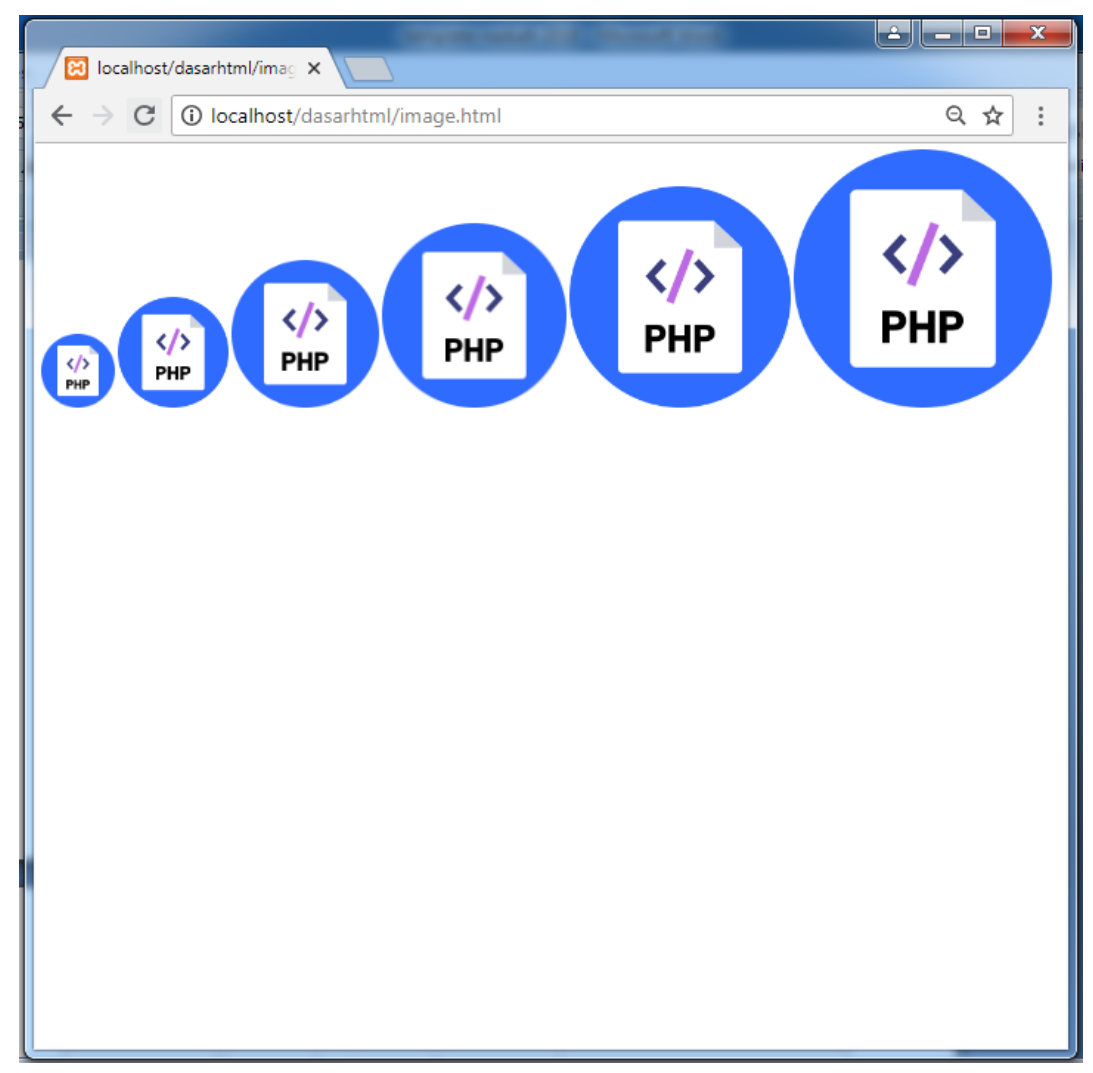

Gambar 1.5 Membuat Gambar dengan Html

6. Membuat Form Dengan Html

\section{Akhir}

<form action="/action_page.php">

<fieldset>

$<$ legend>Form Input Data Siswa: </legend $>$

$$
\text { Nama : <br }>
$$


<input type="text" name="firstname"

value $=$ "Ira" $>\langle$ br $>$

Alamat $:\langle\mathrm{b} r\rangle$

<input type="text" name="lastname"

value="Rantauprapat" $\rangle\langle$ br $\rangle$

No. HP : $\langle\mathrm{b}$ r $>$

<input type="text" name="lastname"

value $=0821 \mathrm{xxx} \times \mathrm{xx} ">\langle\mathrm{b} r\rangle\langle\mathrm{b} r\rangle$

<input type="submit" value="Tambah">

$</$ fieldset $>$

$</$ form $>$

\section{Akhir}




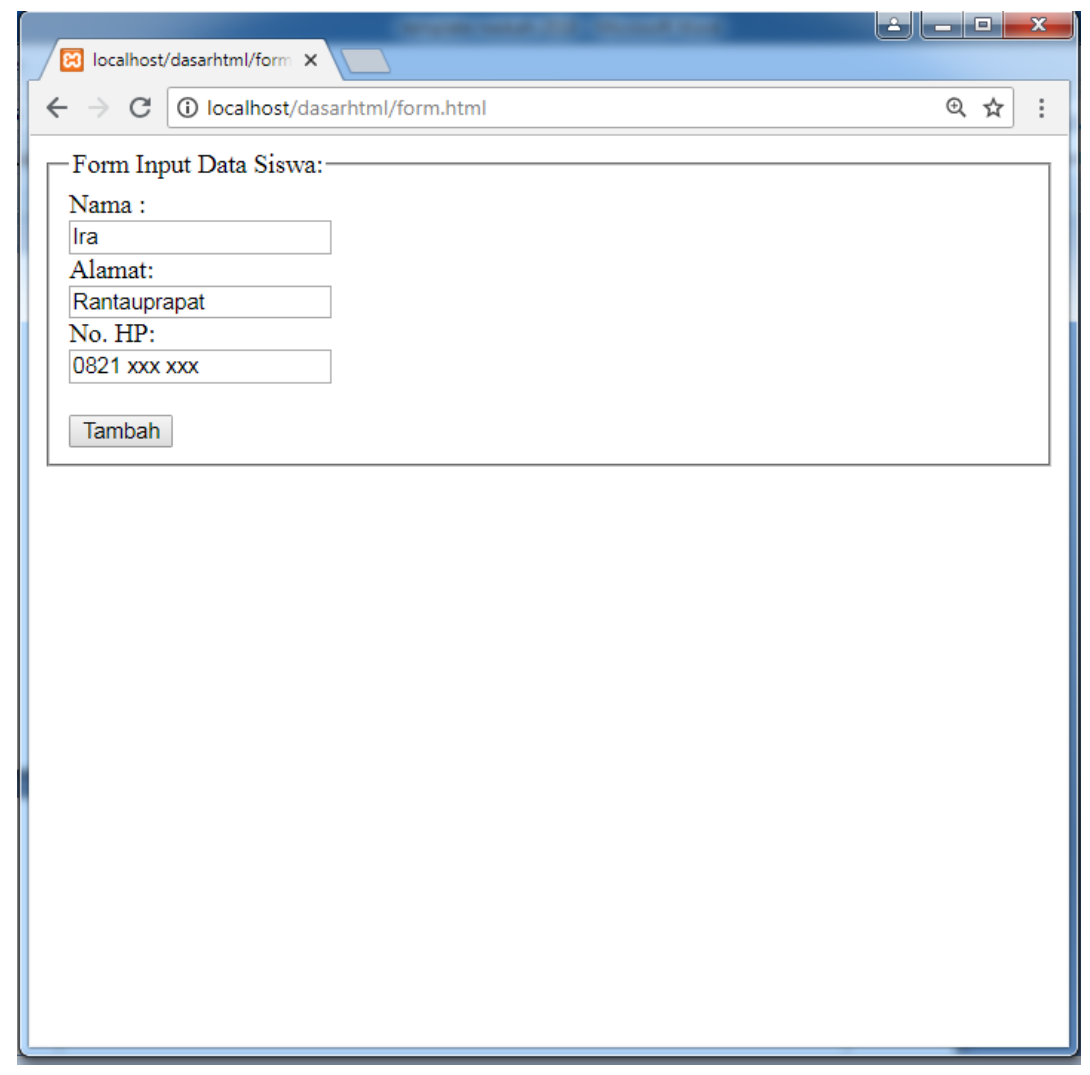

Gambar 1.6 Membuat Form dengan Html 


\section{BAB 2}

\section{CSS}

\subsection{Pengertian CSS}

Dalam bahasa bakunya, seperti di kutip dari wikipedia, CSS adalah "kumpulan kode yang digunakan untuk mendefenisikan desain dari bahasa markup", dimana bahasa markup ini salah satunya adalah HTML.

Untuk pengertian bebasnya, CSS adalah kumpulan kode program yang digunakan untuk mendesain atau mempercantik tampilan halaman HTML. Dengan CSS kita bisa mengubah desain dari text, warna, gambar dan latar belakang dari (hampir) semua kode tag HTML.

CSS biasanya selalu dikaitkan dengan HTML, karena keduanya memang saling melengkapi. HTML ditujukan untuk membuat struktur, atau konten dari halaman web. Sedangkan CSS digunakan untuk tampilan dari halaman web tersebut. Istilahnya, "HTML for content, CSS for Presentation".

\subsection{Fungsi dan Kegunaan CSS}

Awal mula diperlukannya CSS dikarenakan kebutuhan akan halaman web yang semakin kompleks. Pada awal kemunculan HTML, kita bisa membuat suatu paragraf bewarna merah dengan menulis langsung kode tersebut di dalam tag HTML, atau membuat latar belakang sebuah halaman dengan warna biru. Contoh kode HTML untuk hal itu adalah sebagai berikut : 


\section{Awal Skrip}

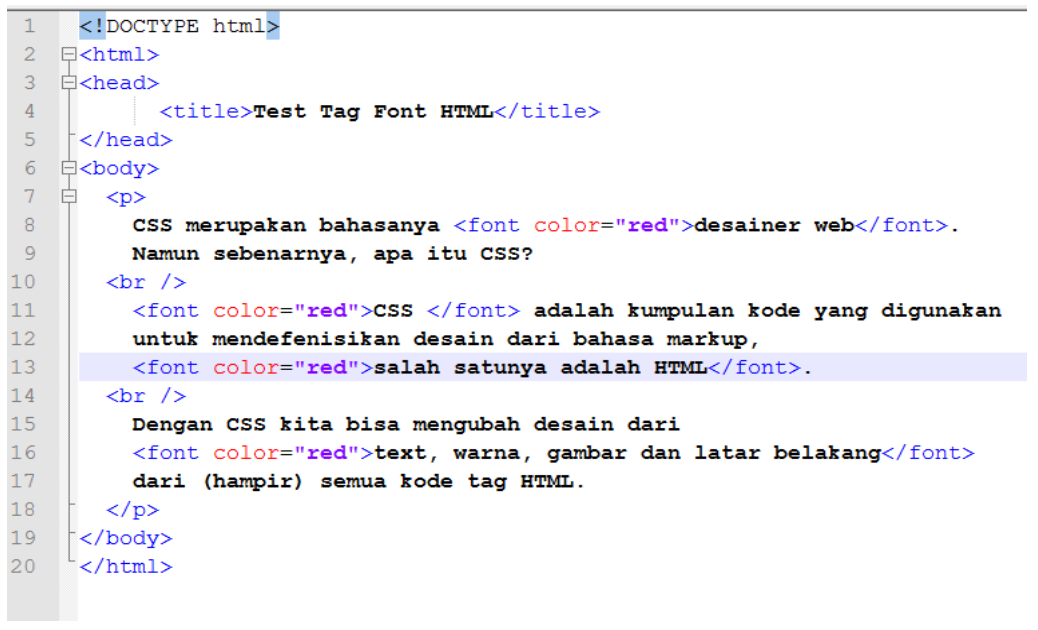

\section{Akhir}

Sistem Informasi Kursus PHP dan MySQL 
ॠ Test Tag Font HTML $\times$

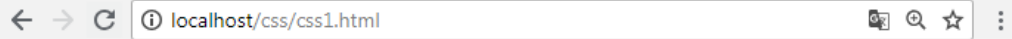

CSS merupakan bahasanya desainer web. Namun sebenarnya, apa itu CSS?

CSS adalah kumpulan kode yang digunakan untuk mendefenisikan desain dari bahasa markup, salah satunya adalah HTML.

Dengan CSS kita bisa mengubah desain dari text, warna, gambar dan latar belakang dari (hampir) semua kode tag HTML.

\section{Gambar 2.1 Contoh Kasus CSS}

Saya menggunakan tag <font> untuk membuat beberapa kata di dalam paragraf tersebut berwarna merah. Hal ini tidak salah, dan semuanya berjalan sesuai keinginan. Untuk sebuah artikel yang memiliki 5 paragraf, kita tinggal copy-paste tag < font color="red"> pada kata-kata tertentu.

Namun setelah website tersebut memiliki katakanlah 50 artikel seperti diatas, dan karena sesuatu hal anda ingin merubah seluruh text 
merah tadi menjadi biru, maka akan dibutuhkan waktu yang lama untuk mengubahnya satu persatu, halaman per halaman. Dalam kondisi inilah CSS mencoba 'memisahkan' tampilan dari konten. Untuk paragraf yang sama, berikut kode HTML bila ditambahkan kode CSS :

\section{Awal Skrip}

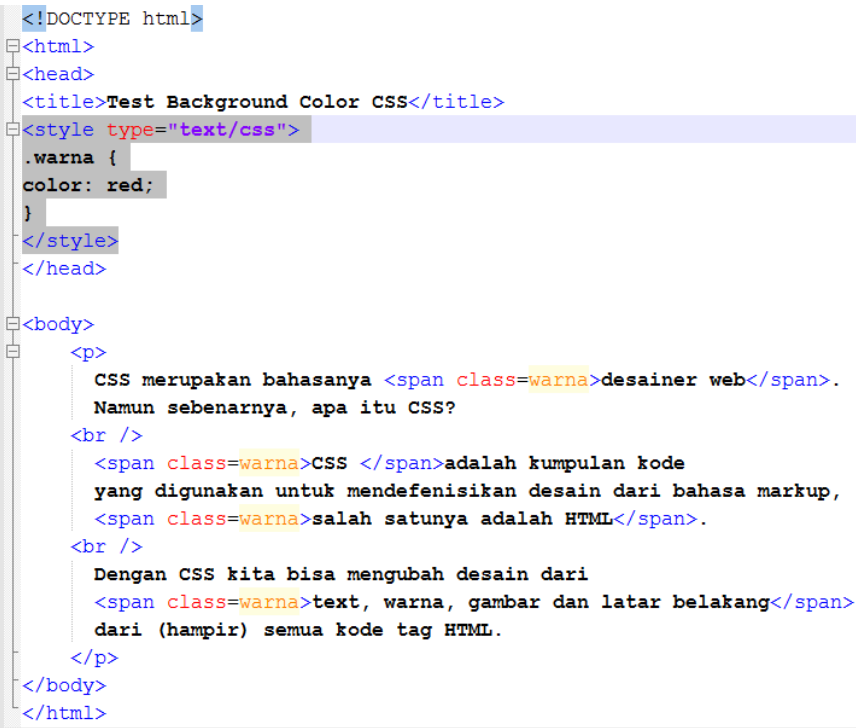

\section{Akhir}


ॠ Test Tag Font HTML $\times$

$\leftarrow \rightarrow$ C (i) localhost/css/css1.html o우 $\odot$

CSS merupakan bahasanya desainer web. Namun sebenarnya, apa itu CSS?

CSS adalah kumpulan kode yang digunakan untuk mendefenisikan desain dari bahasa markup, salah satunya adalah HTML.

Dengan CSS kita bisa mengubah desain dari text, warna, gambar dan latar belakang dari (hampir) semua kode tag HTML.

Gambar 2.2 Merubah Warna dengan CSS

Dalam contoh CSS di atas, saya mengubah tag <font> menjadi tag <span>. Tag <span> sendiri merupakan tag yang tidak bermakna, namun bisa di kostumasi menggunakan CSS. Tag span saya tambahkan dengan atribut atribut class="warna". Atribut class berguna untuk memasukkan kode CSS pada tag <style> di bagian head.

Jika kita ingin merubah seluruh warna menjadi biru, maka tinggal mengubah isi dari CSS color:red menjadi color:blue, dan 
seluruh tag yang memiliki class="warna" akan otomatis berubah menjadi biru.

CSS memungkinkan kita merubah tampilan dari halaman, tanpa mengubah isi dari halaman.

\subsection{Contoh Penggunaan CSS}

1. Membuat Teks (Ke Kanan, Ke Kiri dan Ke Tengah)

\section{Awal Skrip}

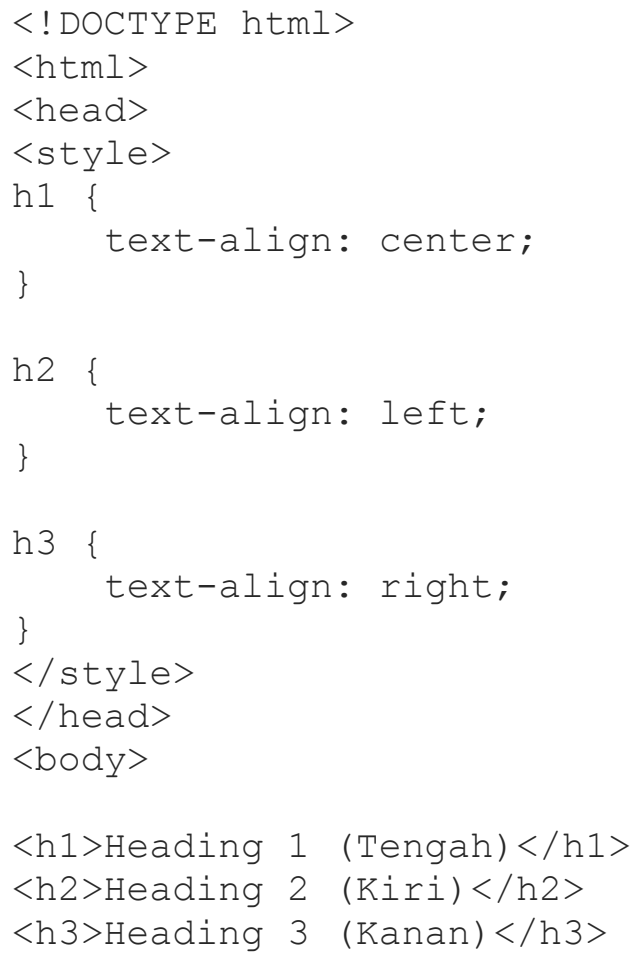


$<$ p Diatas adalah contoh untuk membuat teks ke tengah, ke kiri dan ke kanan $</ p>$

$</$ body $>$

$</$ html $>$

\section{Akhir}

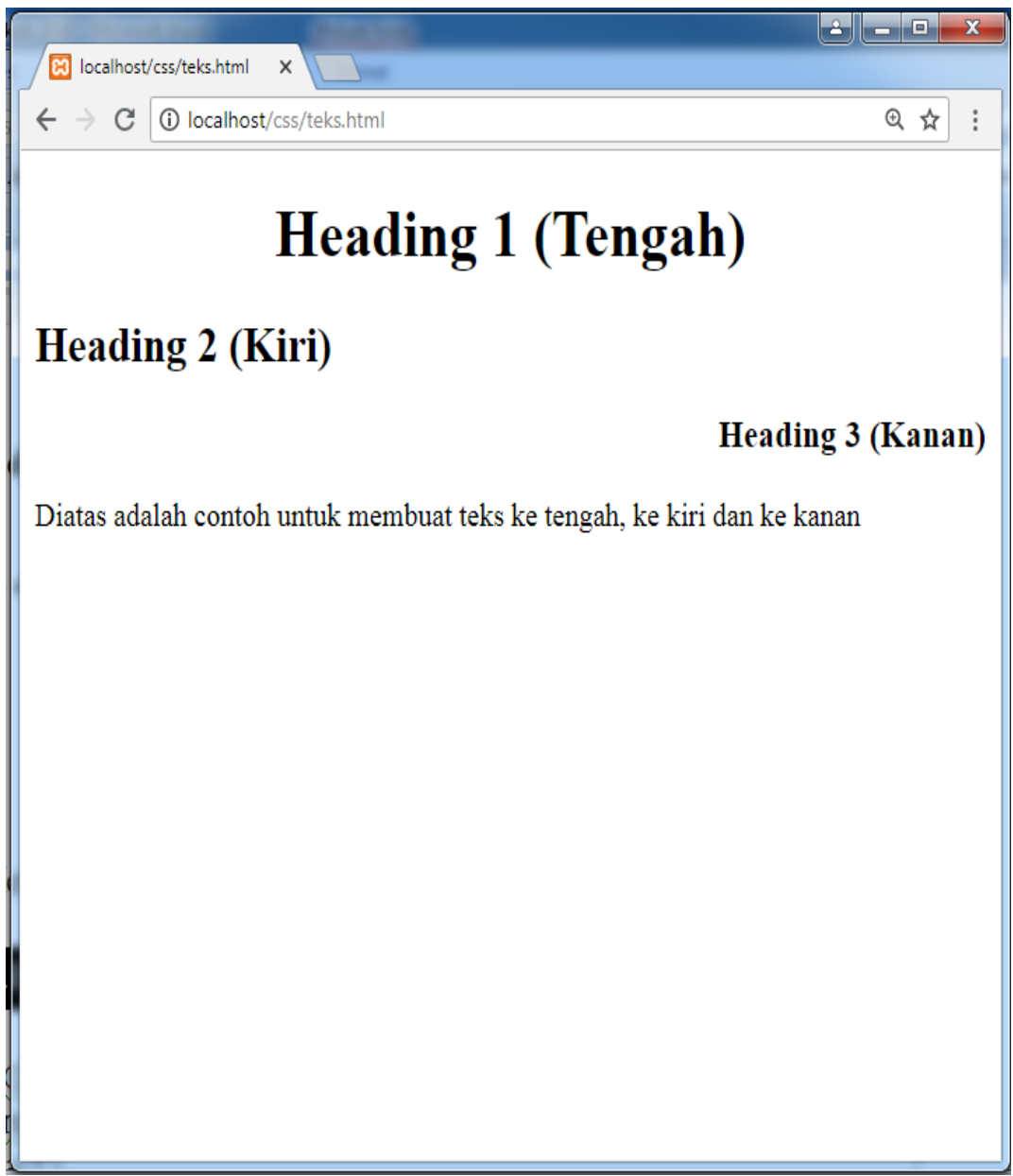

Gambar 2.3 Membuat Teks dengan CSS

Sistem Infarmasi Kursus PHP dan MySDL 
2. Membuat Ukuran Teks

\section{Awal Skrip}

$<$ ! DOCTYPE html $>$

$<$ html $>$

$<$ head $>$

<style>

h1 \{

font-size: 40px;

\}

h2 \{

font-size: 30px;

\}

$\mathrm{p}\{$

font-size: 14px;

\}

$</$ style $>$

$</$ head $>$

$<$ body $>$

$<$ hl>Ukurun Huruf ini 40 Pixel $</$ hl $>$

$<$ h2>Ukurun Huruf ini 30 Pixel $</$ h2 $>$

$<$ p $>$ Ukuran Huruf pada teks ini 14 Pixel. $</$ p $>$

$</$ body $>$

$</$ html $>$

\section{Akhir Skrip}




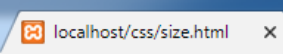

\section{Ukurun Huruf ini 40 Pixel}

\section{Ukurun Huruf ini 30 Pixel}

Ukuran Huruf pada teks ini 14 Pixel.

Gambar 2.4 Membuat Ukuran Teks dengan CSS 


\section{BAB 3}

XAMPP

\subsection{Apa Itu XAMPP ?}

Salah satu aplikasi server localhost serta yang paling banyak digunakan dan cukup familiar di kalangan web developer saat ini adalah XAMPP. XAMPP merupakan aplikasi cross platform: Apache, MySQL, PHP dan Perl. XAMPP juga memberikan solusi sederhana dan cukup ringan dijalankan, memungkinkan Anda membuat web server lokal untuk melakukan pengetesan website.

XAMPP dapat dijalankan pada Mac dan Linux. Dalam buku ini saya akan membahas pada Sistem Operasi Windows.

\subsection{Install XAMPP}

Apa yang dibutuhkan untuk menginstall Xampp ? Untuk memulai langkah pada tutorial ini, Anda memerlukan :

1. Komputer dengan sistem operasi Windows/Linux

2. File installer XAMPP

1. Lakukan instalasi setelah Anda selesai mengunduh di www.apachefriends.org. Selama proses instalasi mungkin Anda akan melihat pesan yang menanyakan apakah Anda yakin akan menginstalnya. Silakan tekan Yes untuk melanjutkan instalasi.

2. Klik tombol Next. 


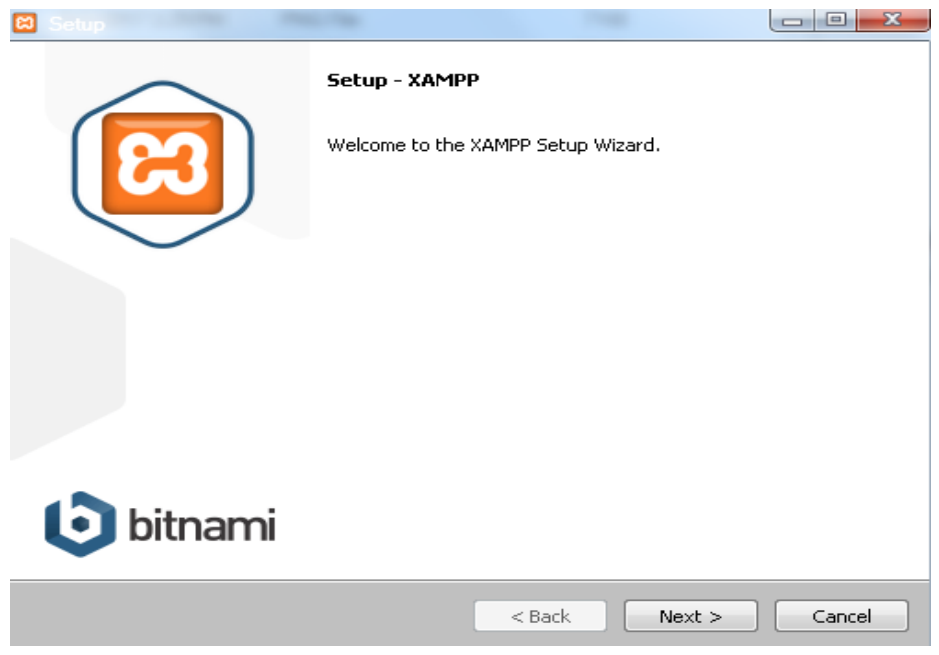

Gambar 3.1 Setup Xampp

3. Pada tampilan selanjutnya akan muncul pilihan mengenai komponen mana dari XAMPP yang ingin dan tidak ingin Anda instal. Beberapa pilihan seperti Apache dan PHP adalah bagian penting untuk menjalankan website dan akan otomatis diinstal. Silakan centang MySQL dan phpMyAdmin, untuk pilihan lainnya biarkan saja. 


\section{Select Components}

Select the components you want to install; clear the components you do not want to install. Click Next when you are ready to continue.

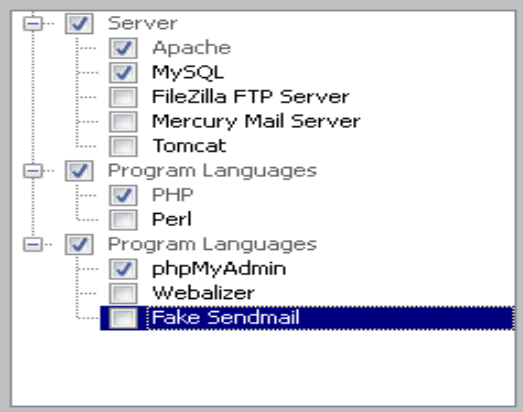

XAMPP Installer

\section{Gambar 3.2 Select Components Xampp}

4. Berikutnya silakan pilih folder tujuan dimana XAMPP ingin Anda install, pada tutorial ini pada direktori $C$ : \xampp.

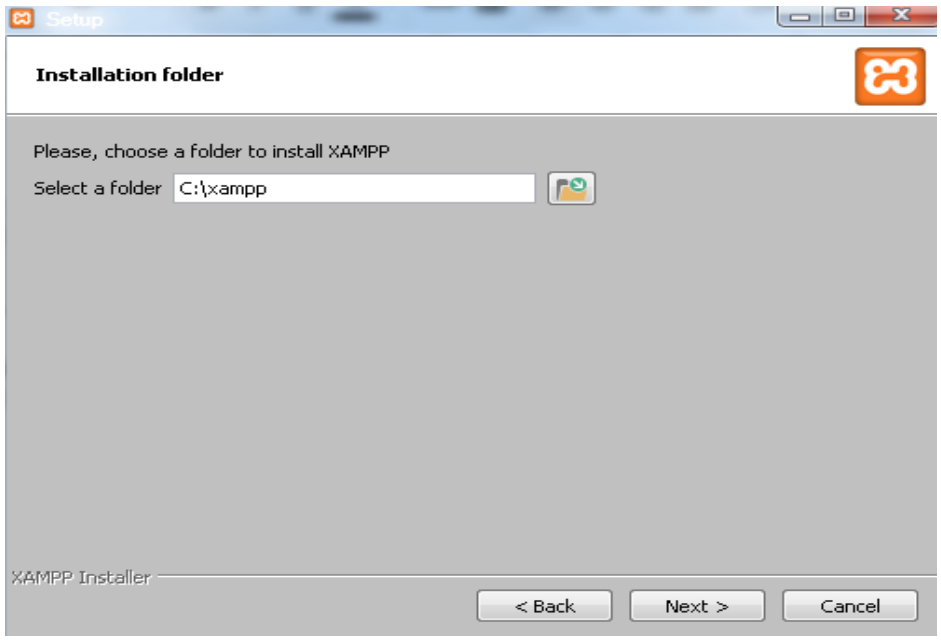

Gambar 3.3 Installation Folder Xampp 
5. Pada halaman selanjutnya, akan ada pilihan apakah Anda ingin menginstal Bitnami untuk XAMPP, dimana nantinya dapat Anda gunakan untuk install WordPress, Drupal, dan Joomla secara otomatis.

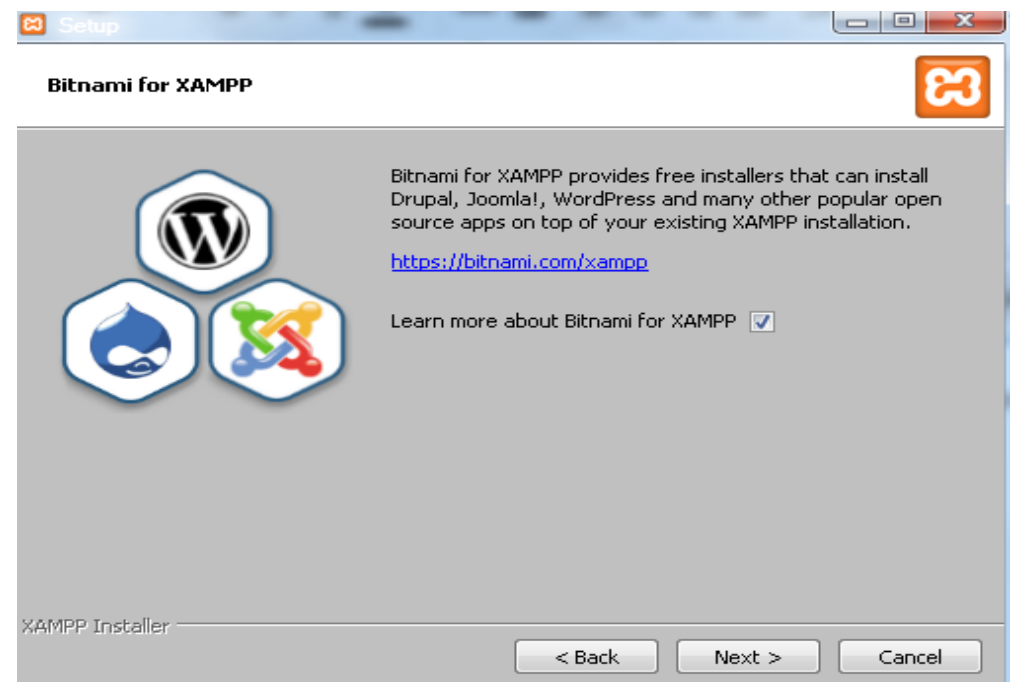

Gambar 3.4 Bitnami for Xampp

6. Pada langkah ini proses instalasi XAMPP akan dimulai. Silakan klik tombol Next. 


\section{Welcome to XAMPP!}

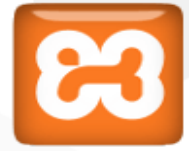

XAMPP is an easy to install Apache distribution containing MySQL, PHP and Perl

Installing

Unpacking files

XAMPP Installer

Gambar 3.5 Bitnami for Xampp

7. Setelah berhasil diinstal, akan muncul notifikasi untuk langsung menjalankan control panel. Silakan klik Finish.

[ Setup

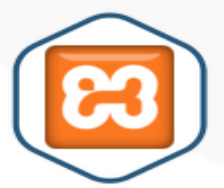

1 bitnami
Completing the XAMPP Setup Wizard

Setup has finished installing XAMPP on your computer.

$\square$ Do you want to start the Control Panel now?

Gambar 3.6 Setup Xampp 


\subsection{Jalankan XAMPP}

Silakan buka aplikasi XAMPP kemudian klik tombol Start pada Apache dan MySQL. Jika berhasil dijalankan, Apache dan MySQL akan berwarna hijau seperti gambar di bawah ini.

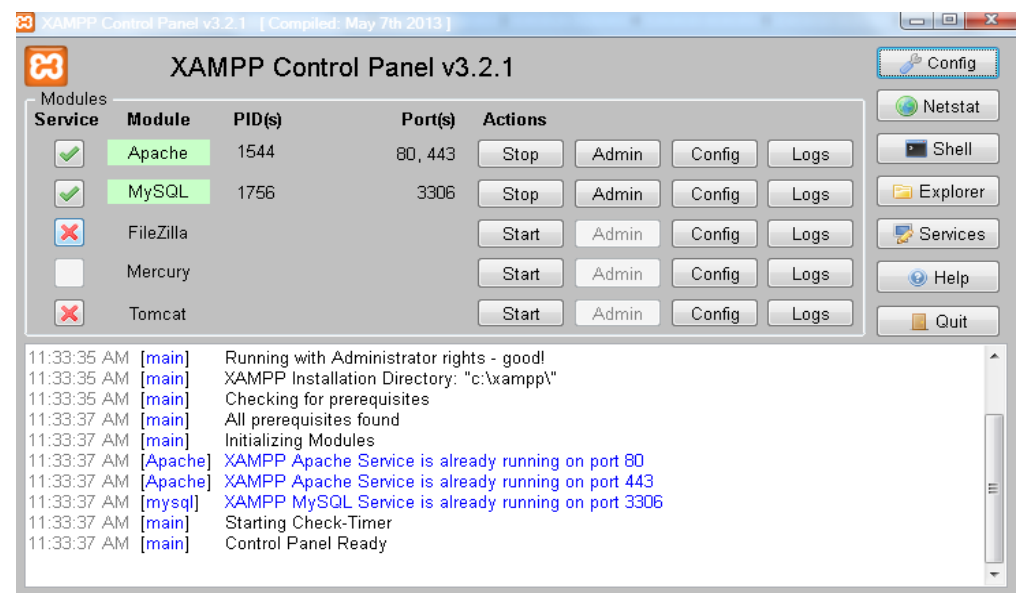

\section{Gambar 3.7 Control Panel Xampp}

Untuk melakukan pengecekan, silakan akses link berikut melalui browser Anda http://localhost. 


\subsection{Membuat Database}

1. Buat database, untuk contoh beri nama "latihan"

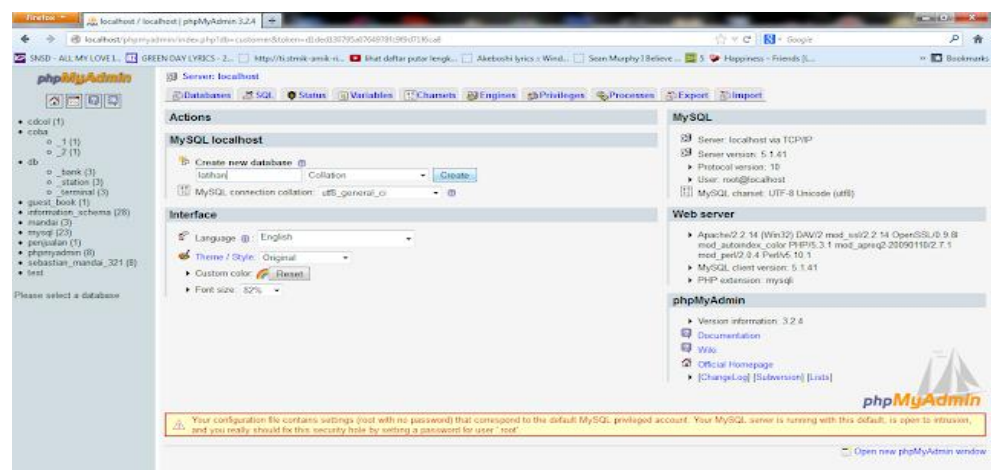

Gambar 3.8 Membuat Database Latihan

\subsection{Membuat Tabel Phpmyadmin}

Buatlah tabel dengan nama "Pelanggan" dan untuk jumlah

field adalah 4

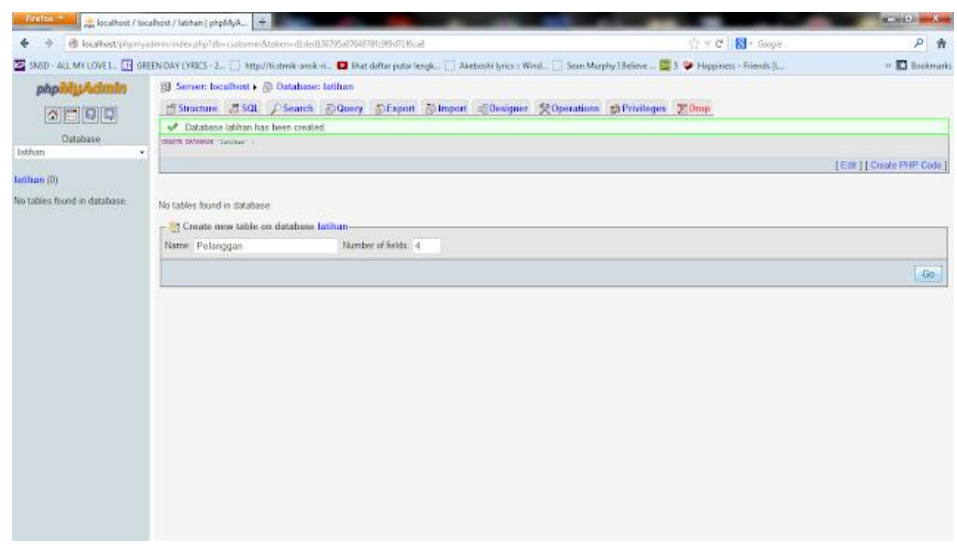

Gambar 3.9 Membuat Tabel Pelanggan

3. Buatlah seperti ketentuan dibawah :

Sistem Informasi Kursus PHP dan MySQL 


\begin{tabular}{|l|l|c|}
\multicolumn{1}{c|}{ Field } & \multicolumn{1}{c|}{ Tipe Data } & Length \\
\hline kd_pelnggan & Char & 5 \\
\hline nm_pelanggan & Varchar & 35 \\
\hline alamat & Varchar & 100 \\
\hline no_hp & Varchar & 13 \\
\hline
\end{tabular}

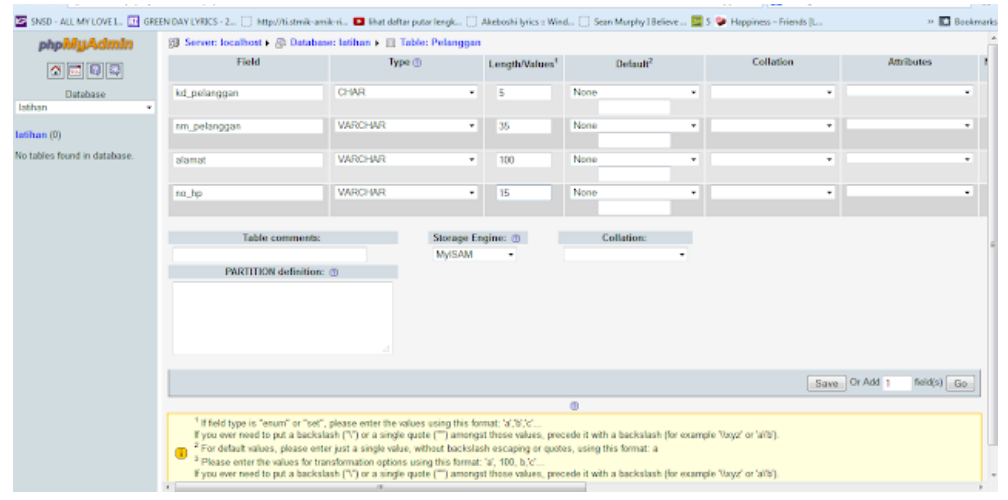

Gambar 3.10 Membuat Field Tabel Latihan

lalu untuk kd_pelanggan berikan status Primary Key 


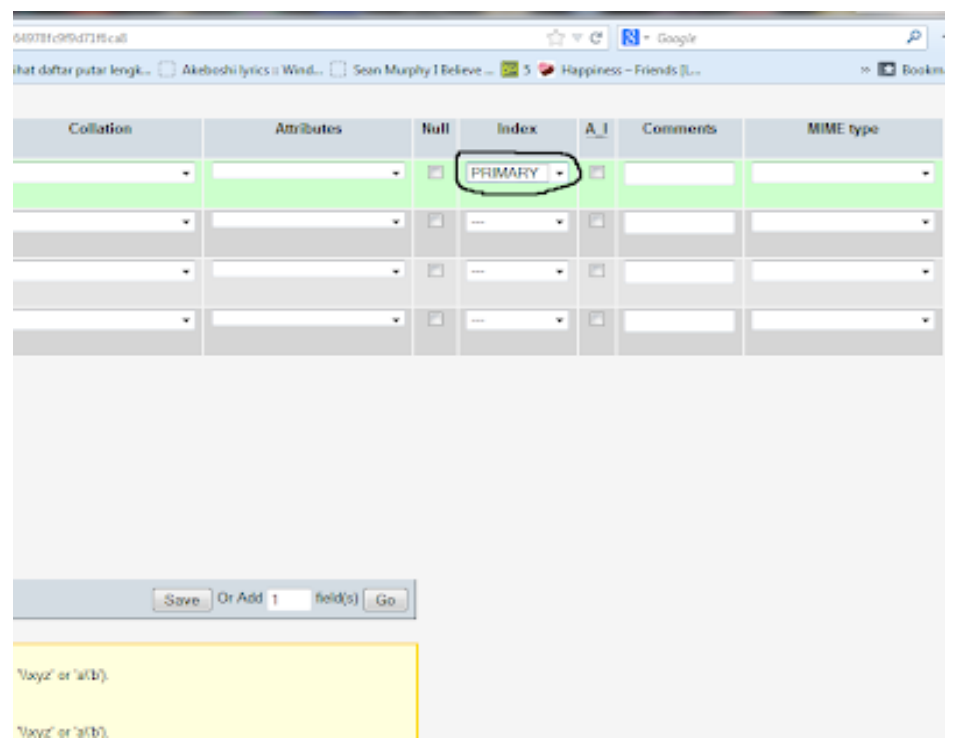

Gambar 3.11 Membuat Primary Keykd_pelanggan

Jika semua telah dilakukan langkah terakhir klik SAVE.

2. Selesai

Berikut tampilannya database dan tabel berhasil dibuat.

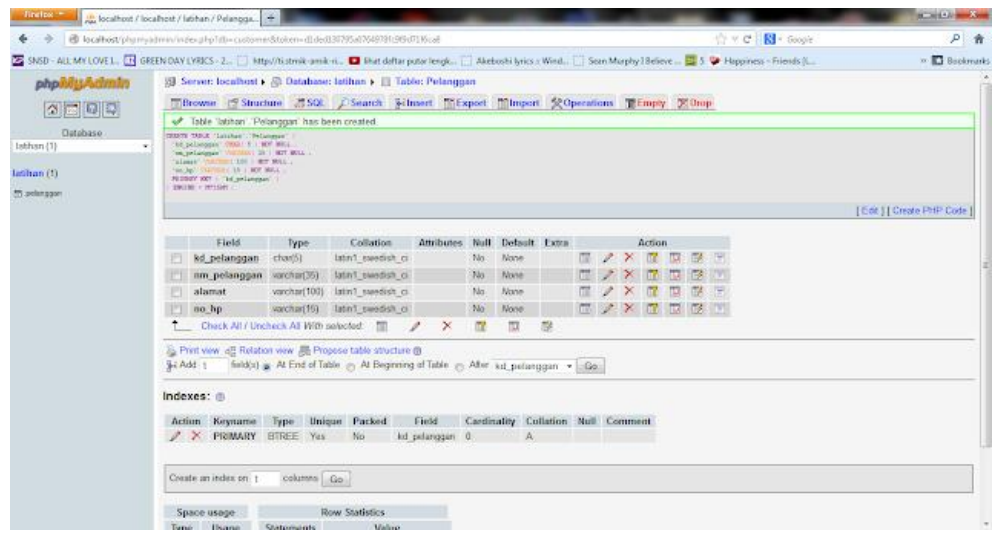

Gambar 3.12 Tampilan Database dan Tabel 


\subsection{Mengedit Tabel Phpmyadmin}

Setelah berhasil membuat tabel, terkadang baru diketahui kemudian bahwa telah terjadi kesalahan atau telah terjadi perubahan pada struktur tabel, termasuk merubah urutan tabel, yang membuat kita perlu untuk meng-edit tabel tersebut.

Untuk mengedit tabel dengan phpMyAdmin, ikuti langkah berikut :

1. Masuk ke struktur tabel. Caranya dapat dilakukan dengan mengklik nama database, kemudian klik link "structure" pada tabel yang diinginkan.

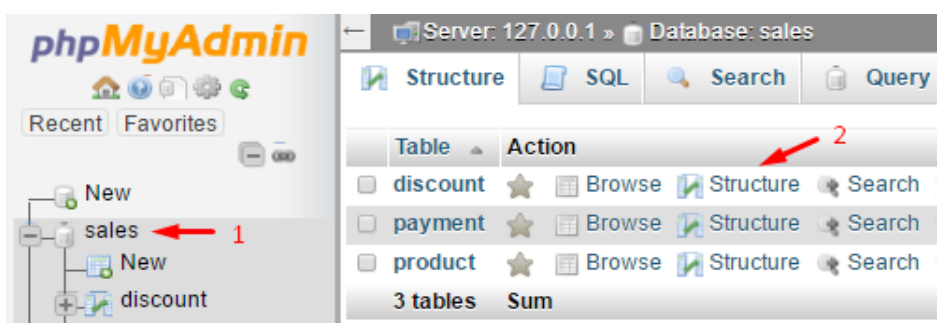

Gambar 3.13 Mengedit Tabel Xampp

atau jika sudah membuka tabel (cirinya di breadcrumbs ada nama tabel) dapat langsung mengklik tab "Structure" yang ada di sebelah atas.

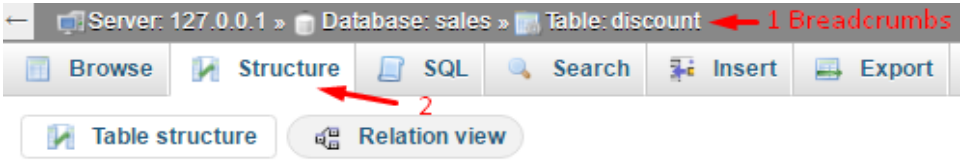

Gambar 3.14 Menu Struktur Tabel Xampp

Sistem Infarmasi Kursus PHP dan MySQL 
2. Selanjutnya tentukan kolom yang ingin diedit kemudian klik link change pada bagian action.

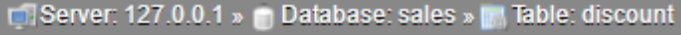

\begin{tabular}{|c|c|c|c|c|c|c|c|c|c|c|c|c|}
\hline 回 & \multicolumn{2}{|c|}{ Browse } & 7 & Struc & ture & $\Xi$ & SQL & Q & \multicolumn{2}{|c|}{ Search } & 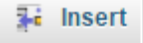 & $\Rightarrow \operatorname{Expc}$ \\
\hline & & \multicolumn{3}{|c|}{ Table structure } & \multicolumn{4}{|c|}{ 喵 Relation view } & \multirow{2}{*}{\multicolumn{2}{|c|}{ Null Def }} & & \\
\hline & \# & Name & & Type & Coll & lation & Attrib & utes & & & ault Extra & stion \\
\hline$\square$ & 1 & id & & $\operatorname{int}(11)$ & & & & & No & Non & & Change \\
\hline$\square$ & 2 & coupo & _id & $\operatorname{int}(11)$ & & & & & No & Non & & Change \\
\hline
\end{tabular}

\section{Gambar 3.15 Tombol Change Xampp}

atau untuk mengedit banyak kolom sekaligus, klik checkbox yang berada di sebelah kiri nama kolom atau klik Check All jika ingin mencentang semuanya, kemudian klik tombol Change yang berada di sebelah bawah.

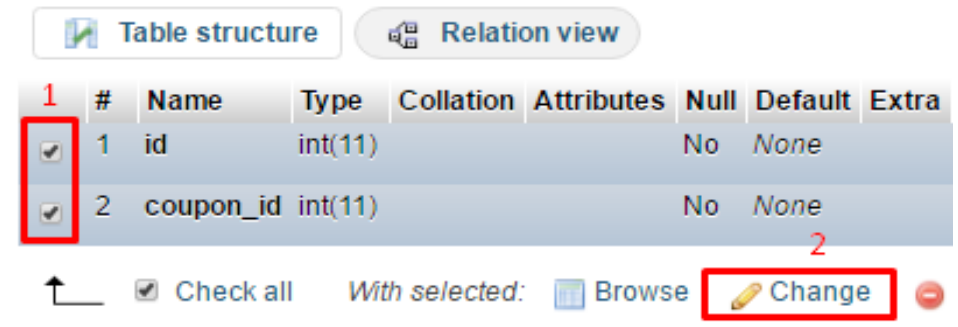

\section{Gambar 3.16 Tombol Check All Xampp}

3. Kemudian ubah parameter yang ada, penjelasan tentang parameter dapat dilihat pada bagian sebelumnya (pembuatan tabel), yang sedikit berbeda dari menu pembuatan tabel adalah 
pada menu edit tabel, terdapat pilihan "Move Column" yang akan digunakan untuk menggeser urutan kolom.

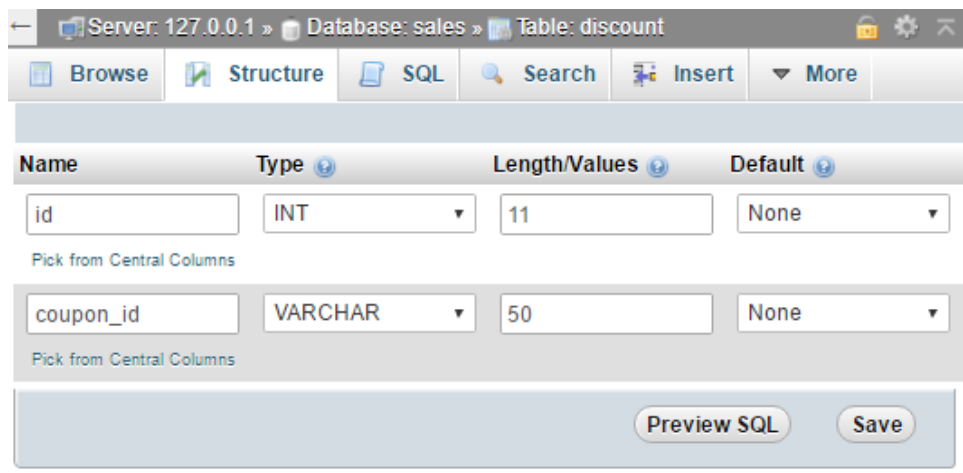

Gambar 3.17 Tombol Move Column Xampp

4. Setelah selesai klik tombol Save

Selesai, demikian cara mengedit tabel dengan phpMyAdmin.

\subsection{Menghapus Tabel Phpmyadmin}

Selanjutnya, terkadang tabel yang ada sudah tidak diperlukan lagi, baik karena terjadi perubahan struktur atau karena hal lain, yang membuat kita perlu untuk menghapusnya.

Untuk menghapus tabel dengan phpMyAdmin, langkah yang kita perlukan adalah:

1. Klik nama database kemudian klik tabel yang ingin dihapus, kemudian klik link "Drop" 


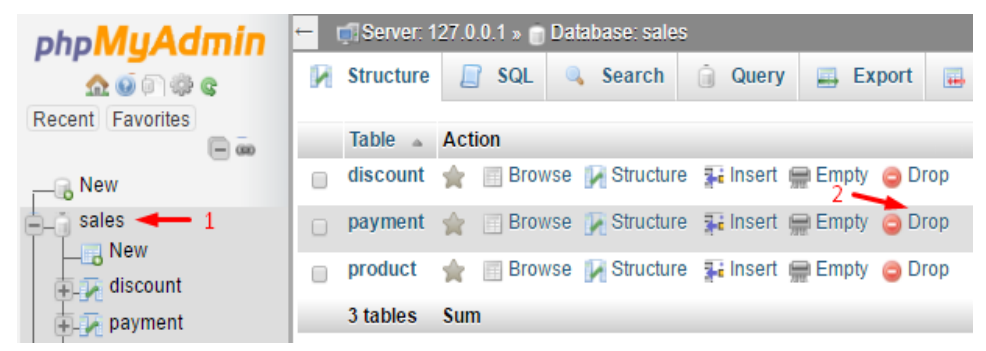

Gambar 3.18 Tombol Drop Xampp

2. Jika ingin menghapus banyak tabel sekaligus, klik checkbox yang ada di sebelah kiri nama tabel kemudian klik dropdown menu "With Selected" yang ada di sebelah bawah, kemudian pilih "Drop".

\section{므 Server: 127 0.0.1 D Database: sales}

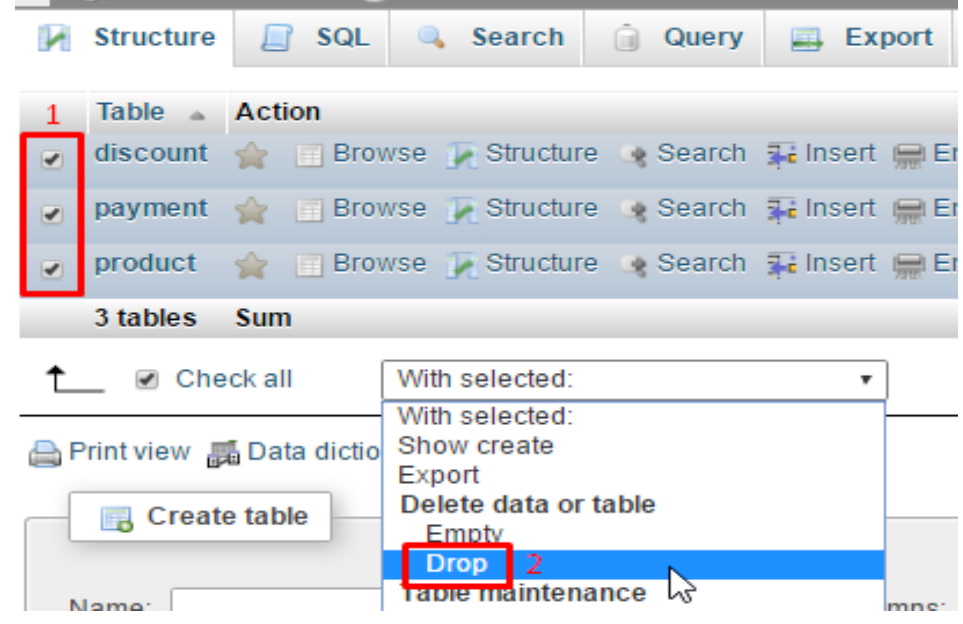

\section{Gambar 3.19 Menghapus Tabel Sekaligus Xampp}

3. Atau jika sedang membuka tabel tersebut (tandanya pada breadcrumb ada link Table) maka bisa langsung mengklik tab 
menu "Operations". Selanjutnya, pada bagian "Delete Data or Table" klik link "delete the table (DROP)"

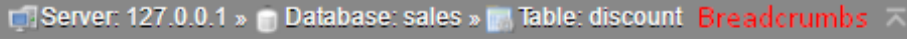

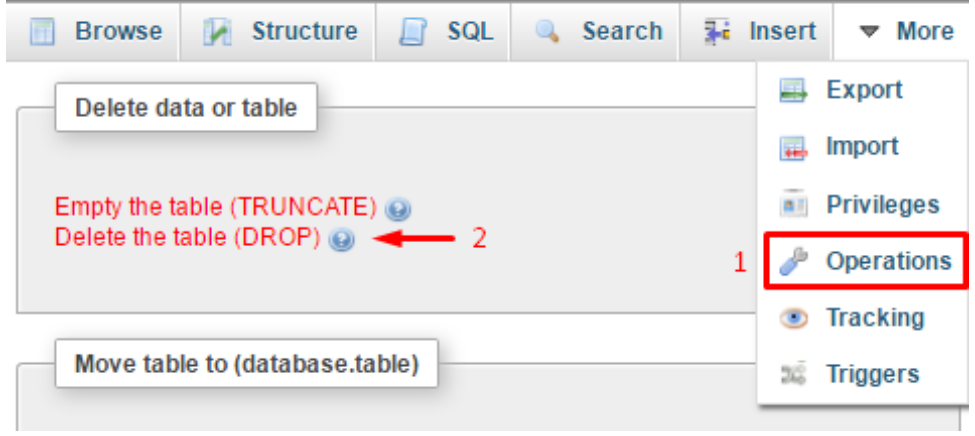

Gambar 3.20 Menu Operation Xampp

Selesai, demikian cara menghapus tabel dengan phpMyAdmin. 


\section{BAB 4 \\ MEMBUAT SISTEM INFORMASI KURSUS}

\subsection{Membuat Database Kursus}

\section{Membuat Tabel Siswa Kursus}

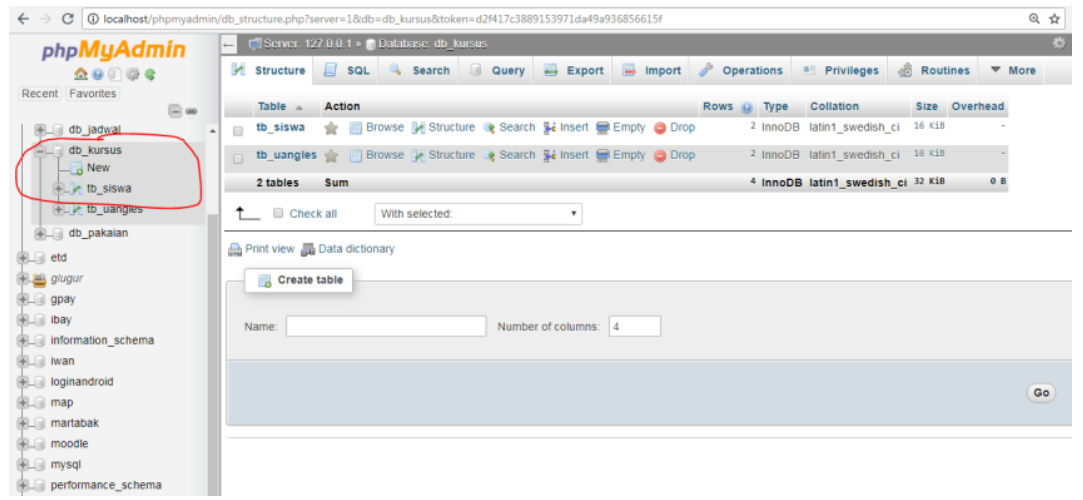

Gambar 4.1 Database Kursus

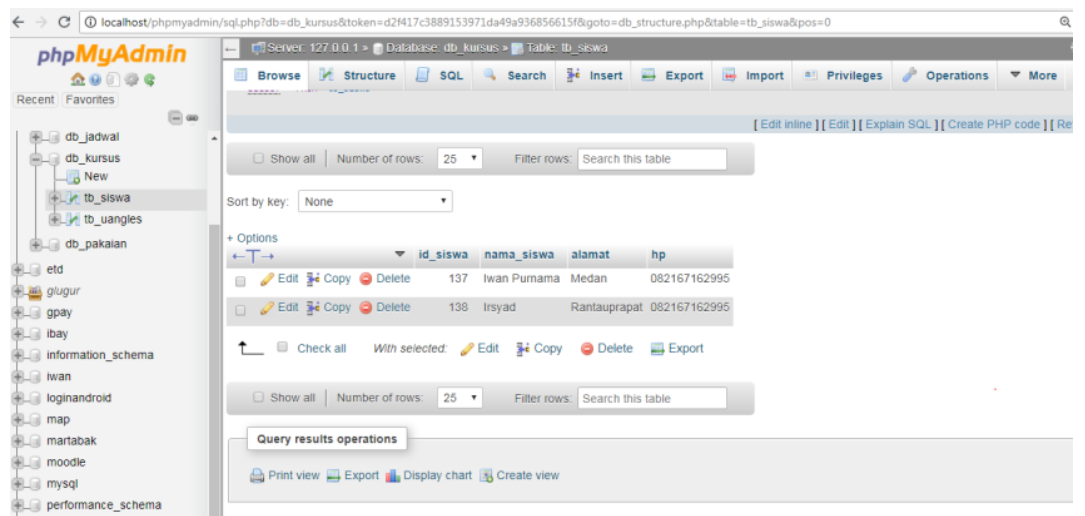

Gambar 4.2 Database Kursus

2. Membuat Tabel Login Admin

Sistem Informasi Kursus PHP dan MySQL 


\subsection{Membuat Scrip PHP}

\section{Membuat Koneksi}

File Koneksi adalah skrip untuk mengubungkan file php dengan database. Berikut skripnya disimpan dengan nama koneksi.php :

\section{1. koneksi.php}

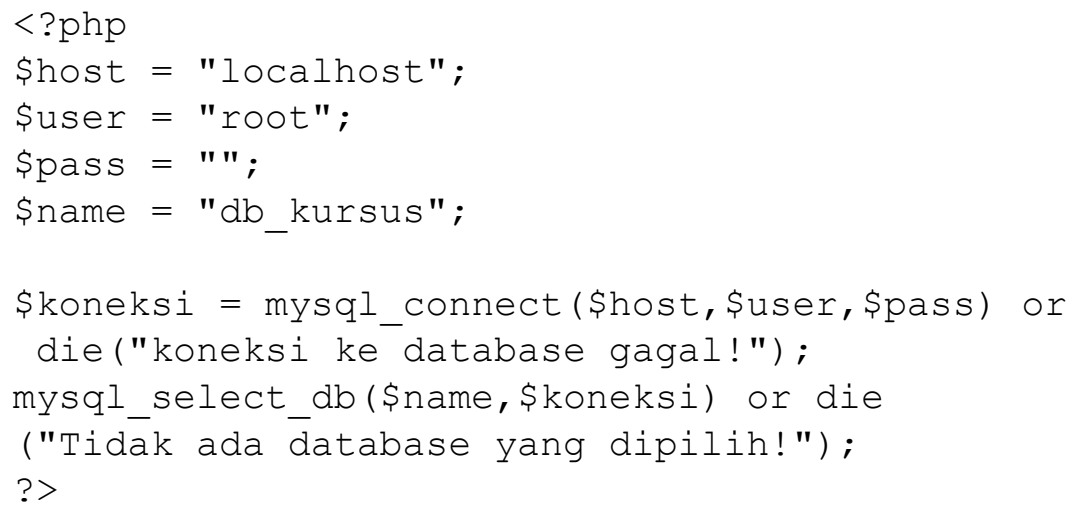

\section{Akhir}

\section{Membuat Halaman Utama}

File halam untama adalah skrip untuk menampilkan aplikasi halaman utama. Berikut skripnya disimpan dengan nama index.php :

\section{Halaman index.php}

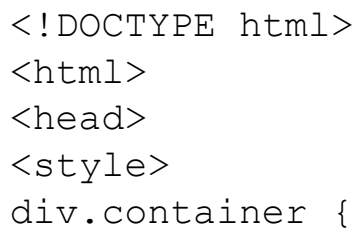


width: $100 \%$;

border: 1px solid gray;

\}

header, footer \{

padding: $1 \mathrm{em}$;

color: white;

background-color: black;

clear: left;

text-align: center;

\}

nav \{

float: left;

max-width: 160px;

margin: 0 ;

padding: $1 \mathrm{em}$;

\}

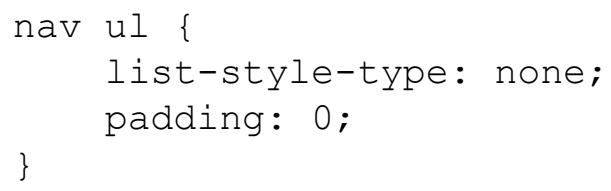


$<$ div class="container" $>$

$<$ header $>$

$<$ hI>SISTEM INFORMASI KURSUS "IBAY KOMPUTER RANTAUPRAPAT"

$</$ h $1>$

$<$ h3>Jl. Dewi Sartika Dekat Rumah Sakit Umum Rantauprapat,

Labuhanbatu, Sumatera Utara $</$ h3 $>$

<h3>Website : <a href="http://IbayKomputer.com">

Ibaykomputer.com</a> | HP : 082167162995 |

Email : ibaykomputeregmail.com</h3>

$</$ header $>$

$<$ nav $>$

$<u l>$

$<$ li $><$ a href="index.php" $>$ Beranda $</ a></ l i>$

$<$ li $><$ a href="siswa.php" $>$ Data Siswa $</ a></ l i>$

$<$ i $><$ a href="instruktur.php" $>$ Data

Instruktur $</ a></$ li $>$

$</ \mathrm{ul}>$

$</$ nav $>$

<article>

$<$ h1 $>$ Welcome $</$ h $1><$ hr $>$

$<$ center ><img src="ibaykomputer.png" height="200" witdh="200" alt="" $></$ center $>$

$<$ p $>$ Selamat datang di Aplikasi Sistem Informasi Kursus

Ibay Komputer Rantauprapat, Jl. Dewi Sartika

Dekat Rumah

Sakit Umum Rantauprapat, Labuhanbatu, Sumatera Utara.

Ibay Komputer adalah salah satu Lembaga Kursus Komputer

berizin Resmi Dinas Pendidikan Labuhanbatu.<br> <ul> 
<li>Kursus Office (Ms. Word,Ms. Excel, Ms.Power Point) </li>

$<$ li>Design Grafis (Adobe Photoshop, Corel

Draw) $</$ li $>$

$<$ i $>$ Teknisi Komputer $</ l i>$

$<$ li>Jaringan Komputer $</ l i>$

$<$ li $>$ Multimedia $</ 1 i>$

$<$ li $>$ Pemrograman $\mathrm{PHP}</ \mathrm{l} i>$

$<l i>$ Pemrograman Visual Basic $</ l i>$

$<$ i $>$ Pemrograman Android $</ l i>$

$</$ ul $>$

$<$ br>Selain Kursus Ibay Komputer juga melayani : $<0 l>$

$<$ li>Service Komputer/Laptop/Printer</li>

$<$ li>Jual Beli Komputer Baru/Seken $</ l i>$

$<$ li>Internet (Browsing, Download) $</$ li $>$

$<$ i $>$ Print/Cetak (Spanduk, Kartu

Nama, Brosur, Undangan dll)

$</ l i>$

$<$ li $>$ Edit Video/Mp3 $</ 1 i>$

$<$ li>Pembuatan Aplikasi/Software/Website</li>

$<$ li>Instalasi Jaringan $</ l i>$

$</ O 1>$

$</ \mathrm{p}>$

$<$ p>Apliaksi ini di Buat Oleh Pemilik Ibay Komputer

Rantauprapat dan Juga salah satu Dosen AMIK Labuhanbatu

Yaitu : Iwan Purnama, S.Kom., M.Kom</p $>$ $</$ article $>$

$<$ footer $>$

Copyright \&copy; Iwan Purnama, S.Kom., M.Kom 2018 $</$ footer $>$

$</$ div $>$

$</$ body $>$

$</$ html $>$

\section{Akhir}

Sistem Infarmasi Kursus PHP dan MySQL 


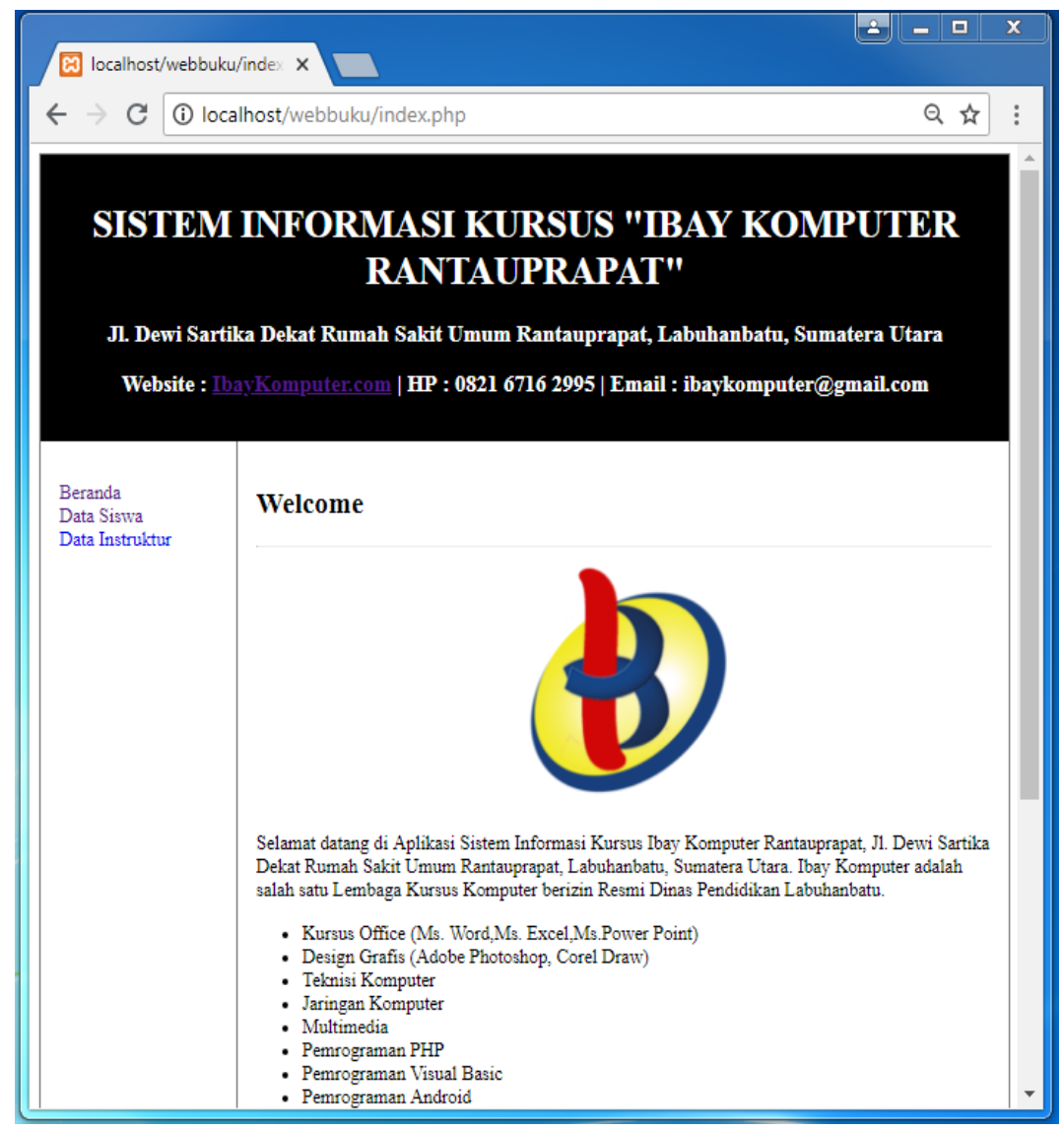

Gambar 4.3Halaman Utama

\section{Membuat Halaman Data Siswa}

Halaman data siswa adalah halaman untuk menampilkan data siswa kursus. Berikut skripnya disimpan dengan nama siswa.php :

\section{siswa.php}

\section{$<$ ! DOCTYPE html $>$}

$<$ html $>$

Sistem Infarmasi Kursus PHP dan MySQL 


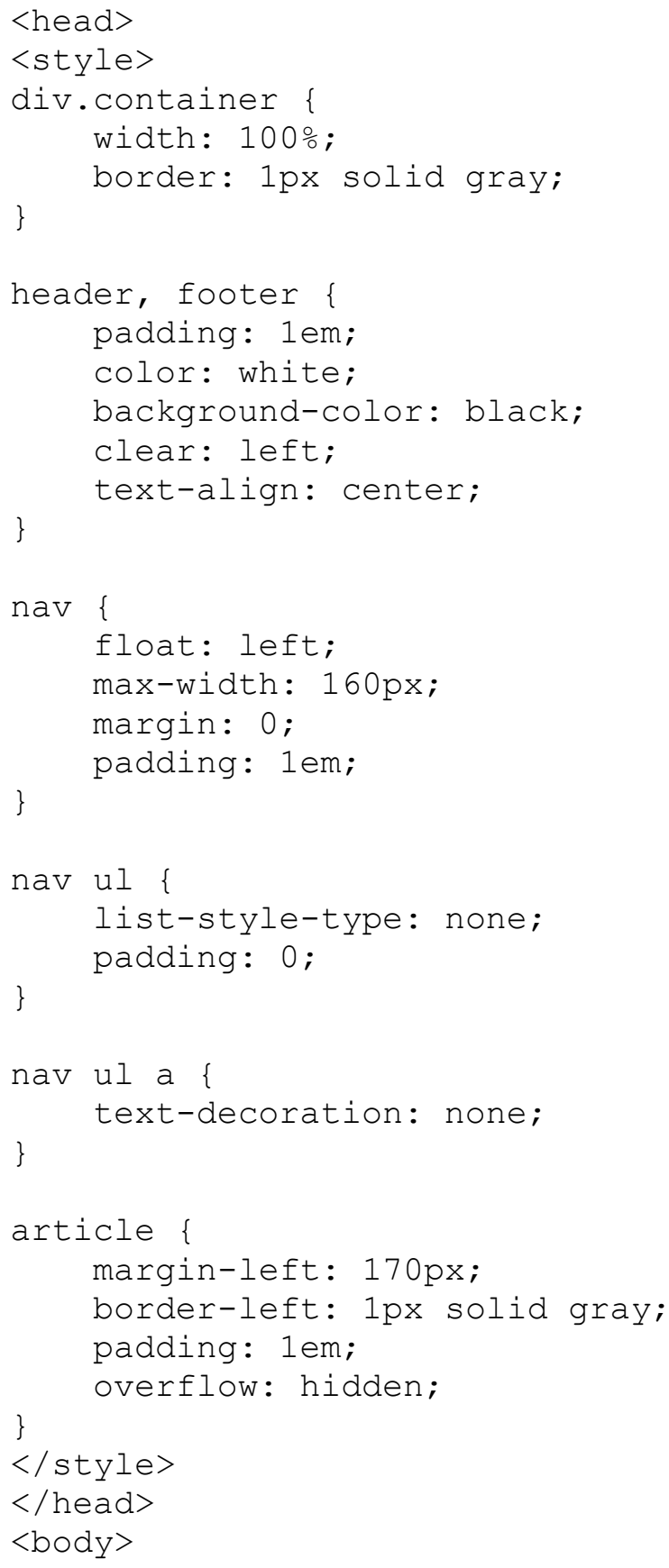


<div class="container">

$<$ header $>$

$<$ hI>SISTEM INFORMASI KURSUS "IBAY KOMPUTER RANTAUPRAPAT" $</$ h1 $>$

$<$ h3>Jl. Dewi Sartika Dekat Rumah Sakit Umum Rantauprapat, Labuhanbatu, Sumatera

Utara $</$ h3 $>$

<h3>Website : IbayKomputer.com | HP : 0821

67162995 | Email :

ibaykomputer@gmail. com $</$ h $3>$

$</$ header $>$

$<$ nav $>$

$<u l>$

$<$ li $><$ a href="index.php" $>$ Beranda $</ a></ 1 i>$

$<$ li $><$ a href="siswa.php" $>$ Data Siswa $</ a></ l i>$

$<1 i><$ a

href="instruktur.php" $>$ Instruktur $</ a\rangle\langle/$ li $\rangle$

$</$ ul $>$

$</$ nav $>$

<article>

$<$ h1 $>$ Data Siswa Kursus $</$ h1 $>$

$<$ a href="tambah_siswa.php" $>$ Tambah Data $</ a>$ <table cellpadding="5" cellspancing="0" border="1">

$<$ tr bgcolor="\#CCCCCC">

$<$ th $>$ No. $</$ th $>$

$<$ th $>$ ID Siswa $</$ th $>$

$<$ th $>$ Nama Siswa $</$ th $>$

$<$ th>Tempat/Tgl Lahir</th $>$

$$
\begin{aligned}
& \quad<\text { th }>\text { HP }</ \text { th }> \\
& <\text { th }>\text { Opsi }</ \text { th }> \\
& </ \text { tr }> \\
& <\text { ?php } \\
& \text { //iclude file koneksi ke }
\end{aligned}
$$

database 
//query ke database dg

SELECT table siswa diurutkan berdasarkan id_siswa paling besar

\$query $=$

mysql_query("SELECT * FROM tb_siswa ORDER BY id_siswa ASC") or die(mysql_error());

//cek, apakah hasil query

di atas mendapatkan hasil atau tidak (data kosong atau tidak)

$==0)\{$

if (mysql_num_rows (\$query)

//ini artinya jika data hasil query diatas kosong

//jika data kosong, maka akan menampilkan row kosong

colspan="6" $>$ Tidak ada data $!</$ td $>\langle/$ tr $>$ ';

$$
\text { \}else\{ //else ini }
$$

artinya jika data hasil query ada (data diu database tidak kosong)

\section{//Jika data}

tidak kosong, maka akan melakukan perulangan while

$$
\$ \mathrm{no}=1 ;
$$

$/ /$ membuat variabel \$no untuk membuat nomor urut

mysql_fetch_assoc(\$query)) \{

while (\$data $=$

//perulangan while dg membuat variabel \$data yang akan mengambil data di database

//menampilkan row dengan data di database $'<t r>$; 


$$
\begin{aligned}
& \text { <footer>Copyright \&copy; Iwan } \\
& \text { Purnama, S.Kom., M.Kom } 2018</ \text { footer }> \\
& \text { </div> } \\
& </ \text { body }> \\
& </ \text { html }
\end{aligned}
$$

\section{Akhir Skrip}

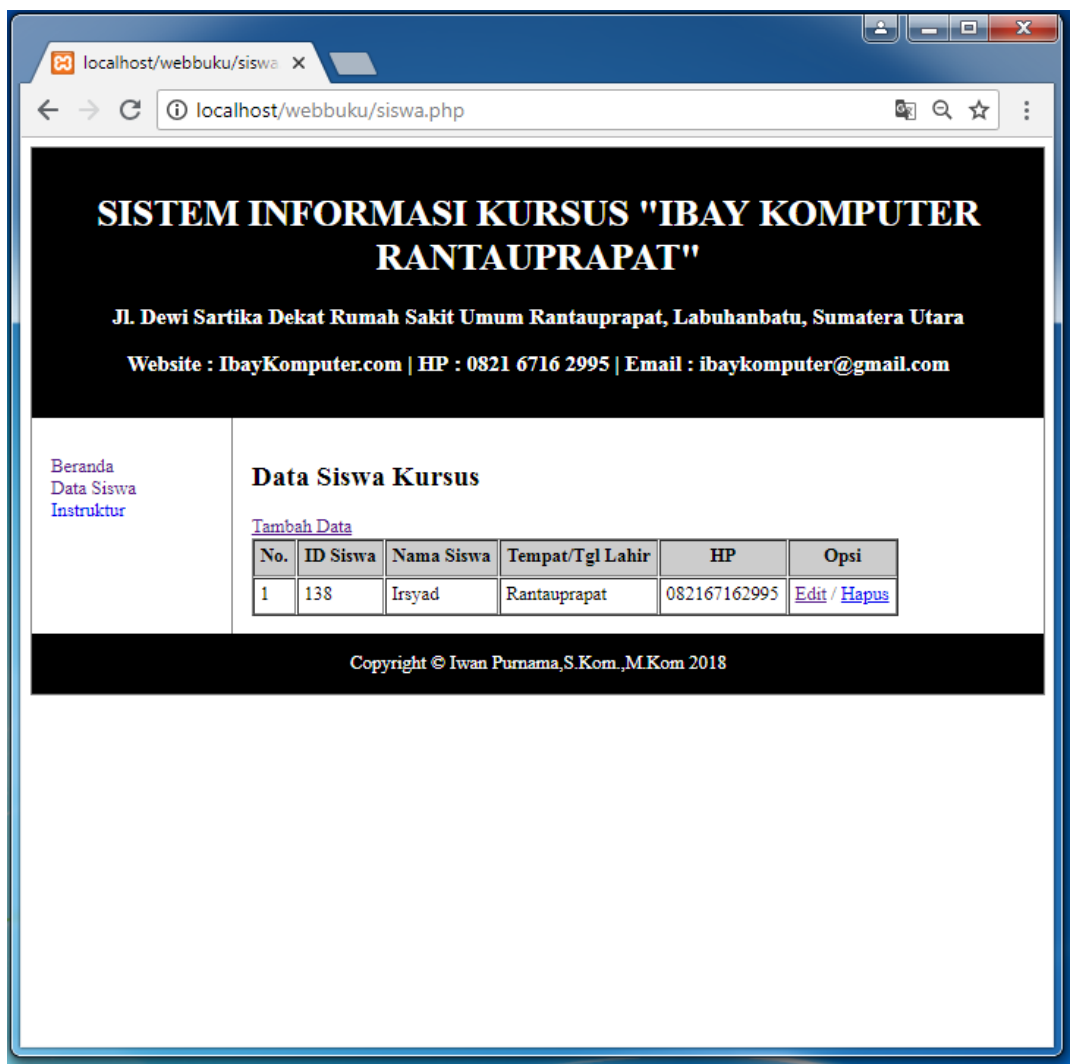

Gambar 4.4Data Siswa

Sistem Infarmasi Kursus PHP dan MySQL 


\section{Membuat Halaman Tambah Siswa}

Halaman tambah siswa adalah halaman untuk menambahkan data siswa yang baru yang terdiri dari nama, alamat dll. Berikut skrip PHP halaman tambah siswa disimpan dengan nama tambah_siswa.php

\section{tambah_siswa.php}

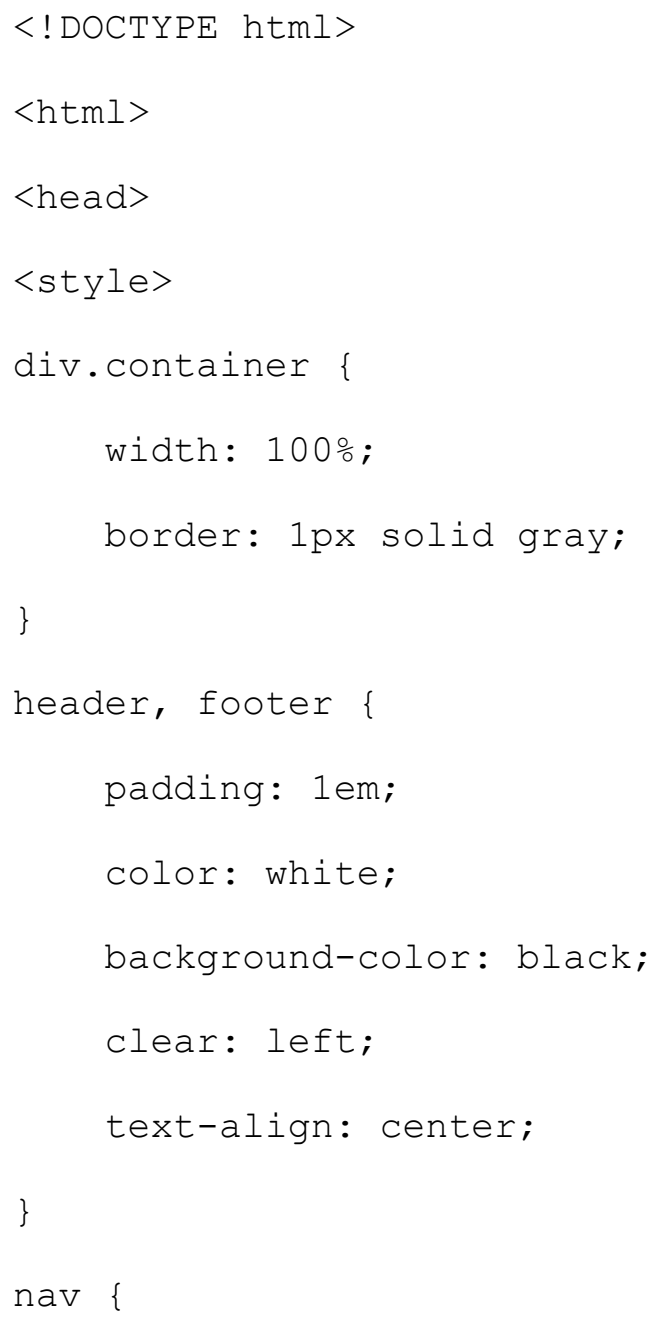


float: left;

max-width: 160px;

margin: 0 ;

padding: 1em;

\}

nav ul \{

list-style-type: none;

padding: 0 ;

\}

nav ul a \{

text-decoration: none;

\}

article \{

margin-left: 170px;

border-left: 1px solid gray;

padding: 1em;

overflow: hidden;

\}

$</$ style $>$

$</$ head $>$

$<$ body $>$

Sistem Infarmasi Kursus PHP dan MySQL 
<div class="container">

$<$ header $>$

$<$ hI>SISTEM INFORMASI KURSUS "IBAY KOMPUTER RANTAUPRAPAT" $</$ h1 $>$

$<$ h3>Jl. Dewi Sartika Dekat Rumah Sakit Umum Rantauprapat, Labuhanbatu, Sumatera Utara</h3>

$<$ h3>Website : Ibaykomputer.com | HP : 08216716 2995 | Email : ibaykomputer@gmail.com</h3> $</$ header $>$

$<$ nav $>$

$<u l>$

$<$ li $><$ a href="index.php" $>$ Beranda $</ a></ 1 i>$

$<$ li $><$ a href="siswa.php" $>$ Data Siswa $</ a></ l i>$

$<$ i $><$ a href="uang_les.php" $>$ Data

Pembayaran $</ a></ 1 \bar{i}>$

$</$ ul $>$

$</$ nav $>$

<article>

<h3>Tambah Data Siswa</h3>

<form action="tambah-proses.php" method="post" $>$

$$
<\text { table cellpadding="3" }
$$

cellspacing="0">

$$
<t r>
$$




$$
\begin{aligned}
& <\text { td }>\text { Nama Lengkap }</ \text { td }> \\
& <\text { td }>:</ \text { td }> \\
& <\text { td }><\text { input type="text" }
\end{aligned}
$$

name="nama_siswa" size="30" required $>\langle/$ td $\rangle$

$$
\begin{aligned}
& </ \operatorname{tr}> \\
& <\operatorname{tr}>
\end{aligned}
$$

$$
\begin{aligned}
& <t d>\text { Alamat }</ \text { td }> \\
& <t d>:</ \text { td }> \\
& <t d><\text { input type="text" }
\end{aligned}
$$

name="alamat" required $></$ td $>$

$$
\begin{aligned}
& </ \operatorname{tr}> \\
& <\operatorname{tr}>
\end{aligned}
$$

$$
\begin{aligned}
& <t d>\operatorname{HP}</ \text { td }> \\
& <t d>:</ \text { td }> \\
& <\text { td }><\text { input type="text" }
\end{aligned}
$$

name="hp" required $></$ td $>$

$$
\begin{aligned}
& </ \text { tr }> \\
& <\text { tr }>
\end{aligned}
$$

$$
\begin{aligned}
& <t d>\& n b s p ;</ t d> \\
& <t d></ \text { td }> \\
& <t d><\text { input type="submit" }
\end{aligned}
$$

name="tambah" value="Tambah" $></$ td $>$ 


$$
\begin{aligned}
& \qquad / \text { tr }> \\
& </ \text { table }> \\
& </ \text { form }> \\
& </ \text { article }> \\
& <\text { footer>Copyright \&copy; Iwan } \\
& \text { Purnama, S.Kom., M.Kom 2018</footer }> \\
& </ \text { div }> \\
& </ \text { body }> \\
& </ \text { html }>
\end{aligned}
$$

\section{Akhir}




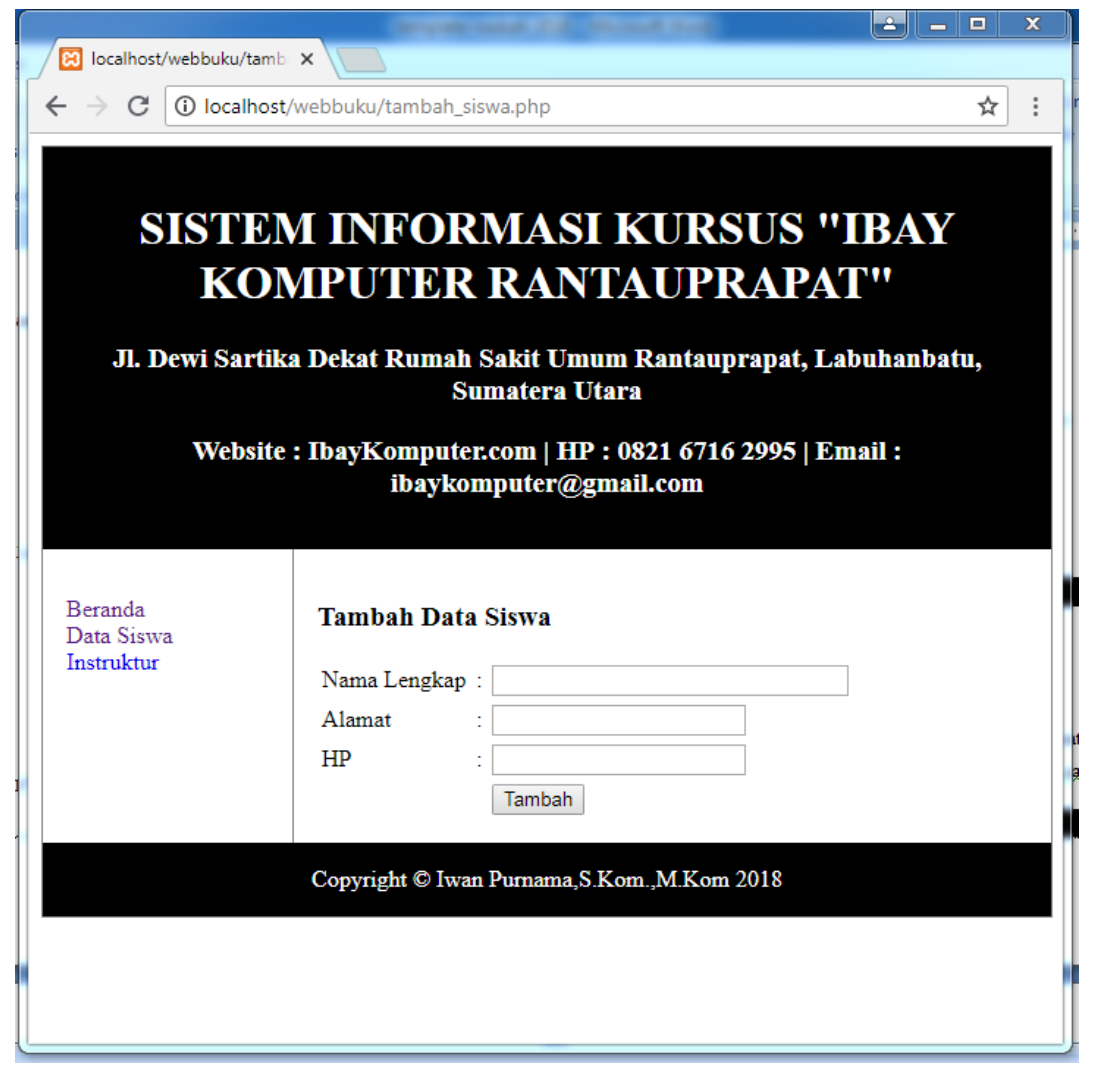

Gambar 4.5 Tambah Siswa

\section{Halaman Edit Siswa}

Halaman edit siswa adalah halaman untuk edit data siswa.

Berikut Halaman edit siswa disimpan dengan nama edit.php.

\section{edit.php}

$<$ ! DOCTYPE html>

$<$ html $>$

Sistem Infarmasi Kursus PHP dan MySQL 
$<$ head $>$

<style $>$

div.container \{

width: $100 \%$;

border: 1px solid gray;

\}

header, footer \{

padding: 1em;

color: white;

background-color: black;

clear: left;

text-align: center;

\}

nav \{

float: left;

max-width: 160px;

margin: 0;

padding: 1em;

\}

nav ul \{

list-style-type: none;

Sistem Infarmasi Kursus PHP dan MySQLL 
padding: 0 ;

\}

nav ul a \{

text-decoration: none;

\}

article \{

margin-left: 170px;

border-left: 1px solid gray;

padding: 1em;

overflow: hidden;

\}

$</$ style $>$

$</$ head $>$

$<$ body $>$

<div class="container">

$<$ header $>$

<h1>SISTEM INFORMASI KURSUS "IBAY KOMPUTER RANTAUPRAPAT" $</$ h1 $>$

$<$ h3>Jl. Dewi Sartika Dekat Rumah Sakit Umum Rantauprapat, Labuhanbatu, Sumatera Utara</h3>

<h3>Website : Ibaykomputer.com | HP : 08216716 2995 | Email : ibaykomputer@gmail.com</h3> 
$</$ header $>$

$<$ nav $>$

$<$ ul $>$

$<$ li $><$ a href="index.php" $>$ Beranda $</ a\rangle / 1 i>$

$<$ li $><$ a href="siswa.php" $>$ Data Siswa $</ a></ l i>$

$<$ i $><$ a href="uang_les.php" $>$ Data

Pembayaran $</$ a $></ 1$ i $>$

$</$ ul $>$

$</$ nav $>$

$<$ article $>$

$<$ body $>$

$<\mathrm{p}><\mathrm{a}$ href="index.php" $>$ Beranda $</ \mathrm{a}>$ /

$<$ a href="tambah.php" $>$ Tambah

Data $</ a></ p>$

$<$ h3 $>$ Edit Data Siswa $</$ h3 $>$

$<$ ?php

include ('koneksi.php') ;

\$id $=\$$ GET['id'] ;

\$show $=$ mysql_query $(" \mathrm{SELECT} *$ FROM tb_siswa WHERE id_siswa='\$id'");

if (mysql_num_rows $(\$$ show $)==0)\{$ 
echo

'<script>window.history.back ()</script>' ;

$$
\text { \}else }\{
$$

\$data $=$ mysql_fetch_assoc (\$show);

\}

?>

<form action="edit-proses.php" method="post">

<input type="hidden" name="id" value="<?php echo \$id; ?>" >

$$
<\text { table cellpadding="3" }
$$

cellspacing="0">

$$
\begin{gathered}
<\text { tr }> \\
<\text { td }>\text { Nama }</ \text { td }> \\
<\text { td }>:</ \text { td }>
\end{gathered}
$$

$$
<\text { td }><\text { input type="text" }
$$

name="nama_siswa"

$$
\text { value=" }<\text { ?php echo }
$$

\$data['nama_siswa']; ? $>$ " required $></$ td $>$

$$
\begin{aligned}
& </ \text { tr }> \\
& <\text { tr }>
\end{aligned}
$$

$$
\begin{aligned}
& <t d>\text { Alamat }</ \text { td }> \\
& <t d>:</ \text { td }>
\end{aligned}
$$


$<$ td $>$ input type="text"

name="alamat" size="30"

$$
\text { value }="<\text { ?php echo }
$$

\$data['alamat']; ?>" required $></$ td $>$

$$
\begin{aligned}
& </ \text { tr }> \\
& <\text { tr }>
\end{aligned}
$$

$<t d>\operatorname{HP}</ t d>$$$
\langle t d\rangle:</ t d\rangle
$$$$
<\text { td }><\text { input type="text" }
$$

name="hp"

$$
\text { value }="<\text { ?php echo }
$$

\$data['hp']; ?>" required $></$ td $>$

$$
\begin{aligned}
& </ \text { tr }> \\
& <\text { tr }>
\end{aligned}
$$

$$
\begin{aligned}
& <t d>\& \text { nbsp; }</ \text { td }> \\
& <t d></ \text { td }> \\
& <t d><\text { input type="submit" }
\end{aligned}
$$

name="simpan" value="Simpan" $></$ td $>$

$$
\begin{aligned}
& </ \text { tr }> \\
& </ \text { table }> \\
& </ \text { form }>
\end{aligned}
$$

$</$ article $>$ 
<footer>Copyright \&copy; Iwan

Purnama, S.Kom., M.Kom 2018</footer>

$</ \operatorname{div}>$

$</$ body $>$

$</$ html $>$

\section{Akhir}

\section{Halaman Hapus}

Halaman hapus adalah halaman untuk menghapus data siswa.

Berikut halaman hapus siswa disimpan dengan nama hapus.php.

\section{hapus.php}

$<$ ?php

if (isset (\$_GET['id'])) \{

include ('koneksi.php');

\$id $=$ \$_GET['id'] ;

\$cek = mysql_query("SELECT id_siswa FROM tb_siswa

WHERE id siswa='\$id'") or

die (mysql_error ()) ;

if (mysql_num_rows $(\$ \mathrm{cek})==0)\{$

echo

'<script>window.history.back ()</script>' ; 


$$
\text { \}else }\{
$$

$$
\text { \$del = mysql_query ("DELETE FROM }
$$

tb_siswa

$$
\begin{aligned}
& \text { WHERE id_siswa='\$id'"); } \\
& \text { if (\$del) }
\end{aligned}
$$

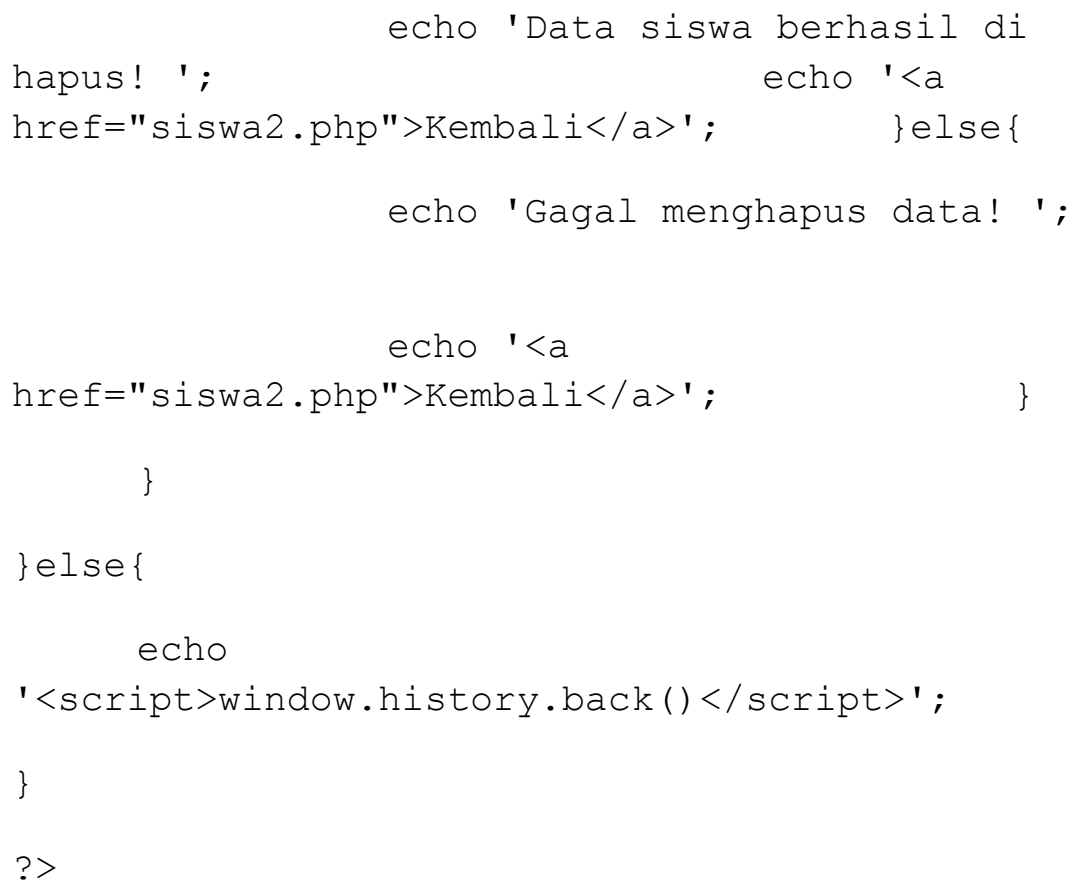

\section{Akhir}




\section{BAB 5 \\ BOOSTRAP}

\subsection{Pengertian Boostrap}

Bootstrap adalah sebuah framework css yang dapat digunakan untuk mempermudah membangun tampilan web. Bootstrap pertama kali di kembangkan pada pertangahan 2010 di Twitter oleh Mark Otto dan Jacob Thornton. Saat ini Bootstrap dikembangkan secara open source dengan lisensi MIT. Kita bisa memantau perkembangan proyek Bootstrap melalui web resminya di getbootstrap.com dan Githubnya di https://github.com/twbs/bootstrap.

Jujur saja, saya sendiri sangat terbantu oleh Bootstrap. Banyak sekali tampilan web yang telah saya buat dengan bantuan Bootstrap,. Bootstrap sangat memanjakan kita dalam membuat tampilan web dan membuat kerja menjadi lebih cepat. Bagaimana tidak, kita tidak lagi harus memulai semuanya dari nol ketika membuat tampilan web. Bootstrap telah menyediakan banyak sekali class CSS dan plugin JavaScript yang bisa langsung kita pakai untuk membantu mempermudah kita membuat halaman web. Karena kemudahaan penggunaan, banyaknya komponen dan kelengkapan dokumentasinya, saat ini Bootstrap menjadi salah satu front-end framework yang paling banyak digunakan di dunia.

Saat buku ini dibuat sebenernya udah ada Bootstrap 4, namun masih versi Alpha. So, kita pakai saja dulu Bootstrap 3-nya yang udah 
stabil untuk memulai belajar sambil menunggu Bootstrap 4 versi stabilnya keluar.

Sebelum kita akan mulai bagaimana cara menggunakan Bootstrap dalam membuat halaman web, kita perlu tahu dulu bagaimana cara Bootstrap itu bekerja. Sehingga nanti kita bisa mengoptimalkan manfaatnya buat pembuatan web kita. Jadi pada dasarnya Bootstrap merupakan sebuah kumpulan class CSS dan plugin JavaScript yang sudah siap pakai. Biasanya kan ketika kita membuat sebuah tampilan web kita akan membuat file HTML yang di dalamnya berisi berbagai macam TAG HTML.

\subsection{Install Boostrap}

Untuk memulainya, pertama-tama kita harus mendownload file Bootstrap terlebih di http://getbootstrap.com/getting-started/.

\section{Getting started}

An overview of Bootstrap, how to download and use, basic templates

and examples, and more.

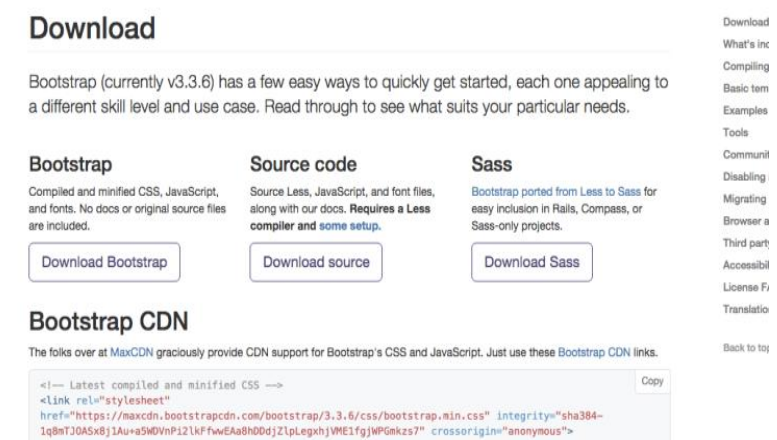

Gambar 5.1 Halaman Web GetBoostrap.com 


\subsection{Desain Web PHP Dengan Tema Boostrap}

Untuk memulai Desain Web dengan Tema Boostrap pertamatama kita harus mendownload file Tema Bootstrap terlebih di https://startbootstrap.com/template-categories/landing-pages/

Start Bootstrap Themes * Snippets Resources * Articles Contact

Premium $=Q$ y 0

\section{Landing Pages}

A collection of free, Bootstrap built landing page and home page

themes and templates.

Q

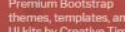

ative Tin

ads via Carbon

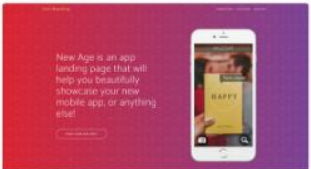

Gambar Website StartBoostrap.com 


\section{Daftar Pustaka (Jika Ada)}

http://getbootstrap.com/

https://html-css-js.com/css/editor/

https://startbootstrap.com

https://www.tutorialspoint.com/html/

https://w3schools.com/ 


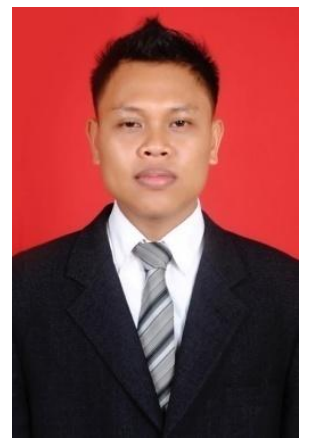

\section{Profil Penulis}

Iwan Purnama lahir di Ajamu pada tanggal 12 Februari 1992. Setelah lulus Sekolah Menengah Atas di Madrasah Aliyah Swasta Al-Ikhlas Ajamu pada tahun 2010, Penulis melanjutkan pendidikan ke AMIK Stiekom Sumatera Utara konsentrasi Manajemen Informatika Komputer dan menyelesaikannnya pada tahun 2013. Pada tahun yang sama, Penulis melanjutkan kembali Pendidikan S1 di STMIK Triguna Dharma Medan dengan memperoleh gelar Sarjana Komputer Sistem Informasi Pada tahun 2014. Selanjutnya penulis melanjutkan pendidikan S2 Komputer di Universitas Putra Indonesia YPTK Padang Sumatera Barat dan memperoleh gelar Magister Sistem Informasi pada tahun 2016.

Penulis sekarang berprofesi sebagai Dosen Tetap AMIK Labuhanbatu, Sofware Developer, Instruktur Kursus Komputer di IbayKomputer.com sekaligus pemilik Ibaykomputer.com. Penulis dapat dihubungi melalui email : iwanpurnama2014@gmail.com atau ibaykomputer@gmail.com 


\section{Tentang Penulis}

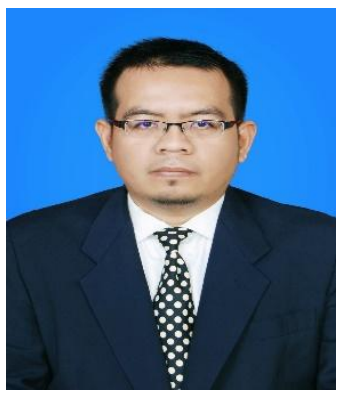

Ronal Watrianthos dilahirkan di Padang pada tanggal 12 Desember 1980. Anak pertama dari empat bersaudara ini menamatkan pendidikan dasar di SDN 13 Padang, SMPN 20 Padang, dan SMAN 6 Padang. Pendidikan tingginya diselesaikan tahun 2004 di Universitas Putra Indonesia 'YPTK' Padang Program Studi Sistem Komputer jenjang pendidikan Strata 1 (S1) dan mendapat gelar Sarjana Komputer (S.Kom). Pada tahun 2013 berhasil menyelesaikan pendidikan Strata II (S2) dan mendapat gelar Magister Komputer (M.Kom) di Universitas Putra Indonesia 'YPTK' Padang dengan kosentrasi jurusan Teknik Informatika.

Memiliki minat yang tinggi terhadap komputer khususnya bidang jaringan dan internet, perangkat keras, open source, serta sistem operasi. Mata kuliah yang diampu adalah Jaringan Komputer, Komunikasi Data, Organisasi Komputer, Sistem Operasi, dan Teknologi Open Source.

Saat ini menjadi dosen tetap di AMIK Labuhan Batu (Yayasan Universitas Labuhanbatu -YULB) Kabupaten Labuhanbatu Sumatera Utara pada Program Studi Manajemen Informatika. Penulis bisa dikontak melalui email: mail.to.ronal@gmail.com 